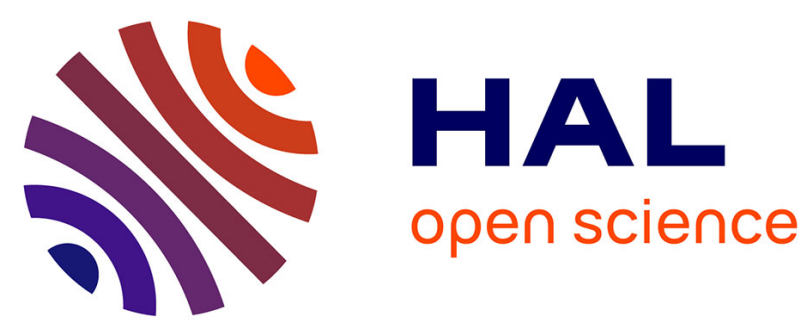

\title{
A novel DOTA-like building block with a picolinate arm for the synthesis of lanthanide complex-peptide conjugates with improved luminescence properties
}

Guillaume Fremy, Laurent Raibaut, Céline Cepeda, Marine Sanson, Margot Boujut, Olivier Sénèque

\section{To cite this version:}

Guillaume Fremy, Laurent Raibaut, Céline Cepeda, Marine Sanson, Margot Boujut, et al.. A novel DOTA-like building block with a picolinate arm for the synthesis of lanthanide complex-peptide conjugates with improved luminescence properties. Journal of Inorganic Biochemistry, 2020, 213, pp.111257. 10.1016/j.jinorgbio.2020.111257 . hal-02944014

\author{
HAL Id: hal-02944014 \\ https://hal.science/hal-02944014
}

Submitted on 21 Sep 2020

HAL is a multi-disciplinary open access archive for the deposit and dissemination of scientific research documents, whether they are published or not. The documents may come from teaching and research institutions in France or abroad, or from public or private research centers.
L'archive ouverte pluridisciplinaire HAL, est destinée au dépôt et à la diffusion de documents scientifiques de niveau recherche, publiés ou non, émanant des établissements d'enseignement et de recherche français ou étrangers, des laboratoires publics ou privés. 


\title{
A novel DOTA-like building block with a picolinate arm for the synthesis of lanthanide complex-peptide conjugates with improved luminescence properties
}

\author{
Guillaume Fremy, ${ }^{\text {ab }}$ Laurent Raibaut, ${ }^{a}$ Céline Cepeda, ${ }^{\text {ab }}$ Marine Sanson, ${ }^{\text {a }}$ Margot Boujut ${ }^{\mathrm{a}}$ and \\ Olivier Sénèque ${ }^{* a}$ \\ ${ }^{\text {a } U n i v . ~ G r e n o b l e ~ A l p e s, ~ C N R S, ~ C E A, ~ I R I G, ~ L C B M ~(U M R ~ 5249), ~ F-38000 ~ G r e n o b l e, ~ F r a n c e . ~}$ \\ ${ }^{\mathrm{b}}$ Univ. Grenoble Alpes, CNRS, DCM (UMR 5250) F-38000 Grenoble, France.
}

Email:olivier.seneque@cea.fr

\begin{abstract}
Combination of complexes of trivalent lanthanide cations $\left(\mathrm{Ln}^{3+}\right)$ for their luminescent properties and peptides for their recognition properties or folding abilities is interesting in view of designing responsive luminescent probes. The octadentate DOTA chelate is the most popular chelate to design luminescent $\mathrm{Ln}^{3+}$ complex-peptide conjugates. In this article, we describe a novel building block, DO3Apic-tris(allyl)ester, which provides access to peptides with a conjugated nonadentate chelate, namely DO3Apic, featuring a cyclen macrocycle functionalized by three acetate and one picolinamide arms, for improved luminescence properties. This building block, with allyl protecting groups, is readily obtained by solid phase synthesis. We show that it is superior to its analogue with $t \mathrm{Bu}$ protecting groups for the preparation of peptide conjugates because of the difficult removal of the $t \mathrm{Bu}$ protecting groups for the latter. Then, two $\mathrm{Zn}^{2+}$-responsive luminescent probes, which rely on (i) a zinc finger scaffold for selective $\mathrm{Zn}^{2+}$ binding, (ii) a Eu${ }^{3+}$ complex and (iii) an acridone antenna for long-wavelength sensitization of $\mathrm{Eu}^{3+}$

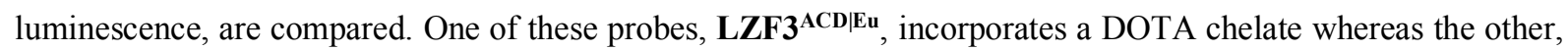
LZF4 $^{\text {ACD|Eu }}$, incorporates a DO3Apic chelate. We show that changing the octadentate DOTA for the nonadentate DO3Apic ligand results in a higher $\mathrm{Eu}^{3+}$ luminescence lifetime and in a doubling of the quantum yield, confirming the interest of the DO3Apic chelate and the DO3Apic(tris(allyl)ester building block for the preparation of $\mathrm{Ln}^{3+}$ complex-peptide conjugates. Additionally, the DO3Apic chelate provides self-calibration for $\mathbf{L Z F}^{\mathbf{A C D} \mid \mathbf{E u}}$ luminescence upon excitation of its picolinamide chromophore, making $\mathbf{L Z F} 4^{\mathbf{A C D} \mid \mathbf{E u}}$ a ratiometric sensor for $\mathrm{Zn}^{2+}$ detection.
\end{abstract}

\section{Keywords}

Peptide - Lanthanide - Chelate - Luminescence - Responsive probe - Zinc 


\section{Introduction}

Luminescence is an affordable and easy-to-use technique that find many applications in biology and medicine as well as environmental sciences [1]. The complexity of biological processes has prompted the development of responsive luminescent probes able to visualize, detect or quantify a specific (bio)analyte or an enzymatic reaction, in biologically relevant conditions. A responsive luminescent probe generally comprises a recognition unit, which binds to or react with a specific analyte or is chemically modified by an enzymatic reaction, and an emissive unit, whose photophysical properties (e.g. excitation or emission spectrum, emission intensity or lifetime) are altered by the status of the recognition unit. In this respect, peptides or proteins that recognize specifically a biological analyte or that are substrate for a specific enzyme are interesting scaffolds to design responsive probes [2,3]. Indeed, these recognition processes are often associated to a conformational change or a cleavage of the peptide/protein that can be used to design sensors relying on the modulation of the energy transfer between a fluorescent donor and an acceptor, fluorophore or quencher, to detect proteins [4], metal cations such as $\mathrm{Zn}^{2+}$ or $\mathrm{Cu}^{+}[5,6]$, activity of enzymes like kinases [4,7] or proteases [4,8,9], as well as physicochemical parameters (ionic strength [10], $\mathrm{pH}[11,12] \ldots$ ).

Nowadays, most luminescent sensors are based on organic dyes but trivalent lanthanide cations $\left(\operatorname{Ln}^{3+}\right)$ are an interesting alternative for biological applications because of their desirable photophysical properties [1318]. Most $\mathrm{Ln}^{3+}$ are luminescent and display sharp emission bands at fixed wavelengths associated to inner-shell 4f-4f transitions [19]. Their emission spectra span the visible and near-infrared ranges. Since $\mathrm{f}-\mathrm{f}$ transitions are forbidden by Laporte rules, lifetimes of $\mathrm{Ln}^{3+}$ excited states are long compared to organic fluorophores (micro-tomillisecond $v s$ nanosecond, respectively), allowing time-resolved detection to suppress short-lived fluorescence of the biological background. Another consequence is the low extinction coefficient of $\operatorname{Ln}^{3+}\left(\varepsilon<10 \mathrm{M}^{-1} \mathrm{~cm}^{-1}\right)$, which makes direct excitation of $\mathrm{Ln}^{3+}$ inefficient. However, this limitation can be overcome in $\mathrm{Ln}^{3+}$ complexes incorporating a suitable chromophore, called antenna, able to absorb light and to transfer energy to the $\mathrm{Ln}^{3+}$ afterwards to populate one of its excited states.

This sensitization process is referred to as antenna effect [20]. The donor state of the antenna may be either a triplet or a singlet state. If the energy of the antenna donor state is too close to the $\mathrm{Ln}^{3+}$ emissive excited state, back energy transfer from the $\mathrm{Ln}^{3+}$ to the antenna can occur, which is detrimental to $\mathrm{Ln}^{3+}$ emission. Ideally, the triplet excited state must lie $2000-4000 \mathrm{~cm}^{-1}$ above the $\mathrm{Ln}^{3+}$ emissive excited state for efficient sensitization [21]. A consequence of the antenna effect is a large separation between excitation and emission wavelengths for $\mathrm{Ln}^{3+}$ complexes, which prevents self-absorption problems. Non-radiative deactivation of the excited state of $\mathrm{Ln}^{3+}$ complexes occurs through high-energy vibrational overtones of $\mathrm{O}-\mathrm{H}, \mathrm{N}-\mathrm{H}$ or $\mathrm{C}-\mathrm{H}$ bonds of the solvent or the ligand. $\mathrm{O}-\mathrm{H}$ oscillators, especially those of $\mathrm{Ln}^{3+}$-bound water molecules, are the most efficient quenchers. Therefore, the hydration number $q$ (i.e. the number of coordinated water molecules) has to be minimized and the $\mathrm{Ln}^{3+}$ has to be shielded from the solvent to maximize its emission.

Some of the photophysical properties of $\mathrm{Ln}^{3+}$ complexes mentioned above can be advantageously exploited to design responsive luminescent probes [15,22-30]. The main strategies include (i) the modulation of the antenna effect by modulation of the distance between the antenna and the $\operatorname{Ln}^{3+}[23,31-33]$ or by modulation of the photophysical properties of the antenna (charge transfer, photoinduced electron transfer ...) induced by binding of the analyte or reaction with it [34-39] and (ii) the modulation of the non-radiative deactivation by playing with the hydration number or with a remote energy acceptor (quencher or fluorophore) [40-45]. Among $\mathrm{Ln}^{3+}, \mathrm{Eu}^{3+}$ combines several advantages to design responsive probes operating in biologically relevant conditions [27]. $\mathrm{Tb}^{3+}$ and $\mathrm{Eu}^{3+}$ complexes present higher quantum yields and brightness compared to other $\mathrm{Ln}^{3+}$ emitting in 
the NIR (e.g. $\mathrm{Sm}^{3+}, \mathrm{Nd}^{3+}$, $\mathrm{Dy}^{3+}$ or $\mathrm{Yb}^{3+}$ ), whose excited states are easily deactivated by $\mathrm{O}-\mathrm{H}$ oscillators of bulk water due to a smaller energy gap between the emissive excited state and the receiving ground $\left(\mathrm{Yb}^{3+}\right)$ or excited $\left(\mathrm{Sm}^{3+}, \mathrm{Nd}^{3+}, \mathrm{Dy}^{3+}\right)$ states. Nevertheless, $\mathrm{Eu}^{3+}$ is more attractive than $\mathrm{Tb}^{3+}$ for several reasons: (i) the biological systems are more transparent to the red emission of $\mathrm{Eu}^{3+}$ than the green emission of $\mathrm{Tb}^{3+}$; (ii) $\mathrm{Eu}^{3+}$ complexes accommodate lower energy excitation with low-lying triplet states antenna because its emissive excited state $\left({ }^{5} \mathrm{D}_{0}\right.$, $\left.E \approx 17300 \mathrm{~cm}^{-1}\right)$ is lower than the one of $\mathrm{Tb}^{3+}\left({ }^{5} \mathrm{D}_{4}, E \approx 20400 \mathrm{~cm}^{-1}\right)$ and (iii) the presence of both environmentinsensitive and hypersensitive transition bands in its emission spectrum allows more possibilities with respect to the probe spectral response, opening the way to ratiometric detection, which is valuable for analyte quantification [46-49].

Several peptide- and $\mathrm{Ln}^{3+}$-based responsive probes have been reported in the literature, in which the peptide acts as (i) a redox switch [33], (ii) a receptor for the targeted analyte, which can be a metal cation [39,50,51], a protein [52-55], an oligonucleotide [56-58] or (iii) the substrate of an enzyme of interest such as kinase or phosphatase [59-61]. The main interest of using a peptide as a recognition element in these probes is the selectivity it provides. Besides, it provides water solubility, which is not always the case with small moleculebased $\mathrm{Ln}^{3+}$ complexes. Most of these peptide- $\mathrm{Ln}^{3+}$ complex conjugate probes feature (i) $\mathrm{Tb}^{3+}$ as a $\mathrm{Ln}^{3+}$, (ii) an antenna - most often tryptophan or an amido derivative of Carbostyril 124 (Cs124) - absorbing below $350 \mathrm{~nm}$ and (iii) a 8- (or less) coordinated $\mathrm{Ln}^{3+}$ complex - most often with a DOTA-monoamide macrocyclic ligand - that leaves space for one (or more) water molecule in the coordination sphere of the $\mathrm{Ln}^{3+}$. These probes are synthetized chemically by solid phase peptide synthesis and conjugation of the chelator is achieved using a polyaminocarboxylate having all its carboxylates except one protected, generally by $t \mathrm{Bu}$ groups. In this respect, the commercially available DOTA-tris $(t \mathrm{Bu})$ ester $[62,63]$ is a building block of choice but DTPA-tetra $(t \mathrm{Bu})$ ester $[64,65]$ or NTA-bis $(t \mathrm{Bu})$ ester [59] were used as well. DOTA and DTPA are octadentate ligands and NTA is a tetradentate one. All three leave the $\mathrm{Ln}^{3+}$ coordinatively unsaturated. Surprisingly, nonadentate polyaminocarboxylate ligands, which could confer superior luminescence properties due to the absence of coordinated water molecules in their $\mathrm{Ln}^{3+}$ complex have never been used to our knowledge to design $\mathrm{Ln}^{3+}$ complex-peptide conjugates as responsive probes.

We have recently described a family of $\mathrm{Zn}^{2+}$-responsive probes based on a classical $\beta \beta \alpha$ zinc finger peptide, for selective $\mathrm{Zn}^{2+}$ binding, conjugated to a DOTA- $\mathrm{Ln}^{3+}$ complex [51,66]. Classical $\beta \beta \alpha$ zinc fingers are short peptides ( $<30$ amino acids) with a (Tyr/Phe)-Xaa-Cys-Xaa2/4-Cys-Xaa3-Phe-Xaas-Leu-Xaa2-His-Xaa3-His consensus sequence, where Xaa can be any amino acid. They adopt a $\beta \beta \alpha$ fold (one two-stranded $\beta$-sheet and a $\alpha$-helix) in their $\mathrm{Zn}^{2+}$-bound form but are unfolded in their $\mathrm{Zn}^{2+}$-free form. Insertion of the DOTA- $\mathrm{Ln}^{3+}$ complex and its antenna on side chains at appropriate positions in the sequence provides luminescent zinc fingers (LZF), for which a shortening of the antenna- $\mathrm{Ln}^{3+}$ distance upon $\mathrm{Zn}^{2+}$ binding results in an increased $\mathrm{Ln}^{3+}$ emission. The first members of this family were based on $\mathrm{Tb}^{3+}$, with tryptophan and Cs124 antennas for LZF1 ${ }^{\mathrm{Trp} \mid \mathrm{Tb}}$ and $\mathrm{LZF1}^{\mathrm{Cs} 124 \mathrm{~Tb}}$ probes, respectively [51]. Cs124 was also used as an antenna to elaborate $\mathrm{LZF} 1^{\mathrm{Cs} 124 \mathrm{Eu}}$, a probe with $\mathrm{Eu}^{3+}$ as an emitter. Although this probe presents an appealing 9.4-fold increase of Eu ${ }^{3+}$ emission in response to $\mathrm{Zn}^{2+}$, it presents $\mathrm{UV}$ excitation below $350 \mathrm{~nm}$ and a low quantum yield for $\mathrm{Eu}^{3+}$ emission $(0.02 \%$ and $0.17 \%$ for the $\mathrm{Zn}$-free and $\mathrm{Zn}$-loaded forms, respectively). In this article, we describe the synthesis of a new prochelator building block, DO3Apic-tris(allyl)ester, and its use in the synthesis a new $\mathrm{Eu}^{3+}$-based LZF probe displaying a nonadentate DO3A-picolinamide chelator, which leaves $\mathrm{Eu}^{3+}$ coordinatively saturated, as well as an acridone antenna, to shift excitation toward higher wavelengths. We compare its luminescence properties with that of the sister probe featuring the classical DOTA-monoamide. 


\section{Experimental}

\subsection{Material and methods}

$\mathrm{N}-\alpha$-Fmoc-protected (L)-amino acids for peptide synthesis, PyBOP and HATU coupling reagents were obtained from Novabiochem or Iris Biotech. SEA-PS resin, 2-chlotrotrityl chloride resin and NovaPEG Rink Amide resin were purchased from X'prochem, Iris Biotech and Novabiochem, respectively. DOTA-tris $(t \mathrm{Bu})$ ester was purchased from CheMatech. Other reagents for peptide synthesis, solvents, buffers and metal salts were purchased from Sigma-Aldrich. All buffer or metal solutions for spectroscopic measurements were prepared with ultrapure water produced by a Millipore Milli- $\mathrm{Q}^{\circledR}$ purification system (purified to $18.2 \mathrm{M} \Omega . \mathrm{cm}$ ). The concentration of the $\mathrm{Zn}^{2+}$ solution was determined by colorimetric EDTA titrations.[67] Buffer solutions were treated with Chelex 100 resin (Bio-Rad) to remove trace metal ions. Analytical HPLC separations were performed on an Agilent Infinity 1260 system using Merck Chromolith RP-18e $(100 \mathrm{~mm} \times 4.6 \mathrm{~mm})$ columns at $2 \mathrm{~mL} / \mathrm{min}$. Preparative HPLC separations were performed on a VWR LaPrep $\Sigma$ system using Waters XBridge Peptide BEH130 C18 $(5 \mu \mathrm{m}, 150 \mathrm{~mm} \times 19 \mathrm{~mm})$ or Waters XBridge Peptide BEH130 C18 (5 $\mu \mathrm{m}, 150 \mathrm{~mm} \times 10 \mathrm{~mm})$ columns at 14 or $6 \mathrm{~mL} / \mathrm{min}$, respectively. Mobile phase consisted in a gradient of solvent $\mathrm{A}\left(0.1 \% \mathrm{TFA}\right.$ in $\left.\mathrm{H}_{2} \mathrm{O}\right)$ and $\mathrm{B}(0.1 \%$ TFA in $\mathrm{MeCN} / \mathrm{H}_{2} \mathrm{O} 9: 1$ ). For analytical separations, Method A consisted in 5\% B during 1 min followed by a 5 to $50 \% \mathrm{~B}$ gradient in $14 \mathrm{~min}$ at $2 \mathrm{~mL} / \mathrm{min}$. Eluate was monitored by electronic absorption at 214, 280 and $331 \mathrm{~nm}$. LRMS analyses were performed on a Thermo Scientific LXQ spectrometer. HRMS analyses were performed on a Waters Xevo G2-S QTof spectrometer with electrospray ionization. ${ }^{1} \mathrm{H}$ and ${ }^{13} \mathrm{C}$ NMR spectra were recorded on a Bruker Avance III 400 spectrometer. Chemical shifts were referenced to residual solvent peak or external reference (sodium trimethylsilylpropanesulfonate for ${ }^{13} \mathrm{C}$ spectra in $\mathrm{D}_{2} \mathrm{O}$ ). UV-Vis absorption spectra were recorded on a Perkin-Elmer Lambda 35 spectrophotometer equipped with a thermo-regulated cell holder (298 K).

\subsection{Synthesis of protected macrocyclic ligands}

\subsubsection{DO3Apic-tris(allyl)ester}

A solution of 6-(chloromethyl)picolinic acid [68] (0.9 mmol, 1 eq., $150 \mathrm{mg})$ and DIEA (2 mmol, 2 eq., $350 \mu \mathrm{L}$ ) in DCM was reacted with an excess of 2-chlorotrytil chloride resin (7 mmol, 7 eq., $5 \mathrm{~g})$ for $45 \mathrm{~min}$. After washing $(2 \times \mathrm{DCM})$, the remaining reactive resin was capped with DCM/MeOH/DIEA (17:2:1 v:v:v, $10 \mathrm{~mL}$, $2 \times 10 \mathrm{~min})$. After washing $(4 \times \mathrm{DCM})$, a solution of cyclen $(3 \mathrm{mmol}, 3 \mathrm{eq}$., $517 \mathrm{mg})$ and DIEA (20 mmol, 20 eq., $3.5 \mathrm{~mL})$ in DCM was added on the resin for $4 \mathrm{~h}$. The resin was washed $(3 \times \mathrm{DCM}, 2 \times \mathrm{DMF}, 2 \times \mathrm{DCM}, 2 \times \mathrm{DMF})$. A solution of allyl chloroacetate (10 mmol, 10 eq., $1.2 \mathrm{~mL})$ and DIEA (10 mmol, 10 eq., $1.7 \mathrm{~mL})$ in DMF was added to the resin and stirred for $12 \mathrm{~h}$. After DMF washing, the allyl chloroacetate solution was renewed and allowed to stirred for $24 \mathrm{~h}$. After washing $(3 \times \mathrm{DCM}, 2 \times \mathrm{DMF}, 2 \times \mathrm{DCM})$ the resin was washed with $\mathrm{Et}_{2} \mathrm{O}$ and dried. Cleavage was performed using TFE/DCM $(2: 3 \mathrm{v} / \mathrm{v}, 25 \mathrm{~mL}, 2 \mathrm{~h})$ and the resin was washed twice with DCM. The product was evaporated under pressure to give an oily residue. After HPLC purification and freeze-drying, DO3Apictris(allyl)ester was obtained as an oil (0.415 mmol, $250 \mathrm{mg}, 46 \%$ ). ${ }^{1} \mathrm{H} \mathrm{NMR}\left(400 \mathrm{MHz}, \mathrm{CD}_{2} \mathrm{Cl}_{2}, 300 \mathrm{~K}\right): \delta=3.21$ (br s, $4 \mathrm{H}, \mathrm{NCH}_{2} \mathrm{CH}_{2} \mathrm{~N}$ ), 3.26 (br s, $4 \mathrm{H}, \mathrm{NCH}_{2} \mathrm{CH}_{2} \mathrm{~N}$ ), 3.47 (br s, $4 \mathrm{H}, \mathrm{NCH}_{2} \mathrm{CH}_{2} \mathrm{~N}$ ), 3.56 (br s, $8 \mathrm{H}, \mathrm{NCH}_{2} \mathrm{CH}_{2} \mathrm{~N}+$ $\mathrm{CH}_{2} \mathrm{COO}$ allyl), 4.13 (br s, 2H, $\mathrm{CH}_{2} \mathrm{COO}$ allyl), 4.59 (m, 4H, $\mathrm{CH}_{2}-\mathrm{CH}=\mathrm{CH}_{2}$ ), 4.63 (br s, 2H, $\left.\mathrm{CH}_{2} \mathrm{Py}\right), 4.69$ (m, $2 \mathrm{H}$, $\left.\mathrm{CH}_{2}-\mathrm{CH}=\mathrm{CH}_{2}\right), 5.22-5.44\left(\mathrm{~m}, 6 \mathrm{H}, \mathrm{CH}=\mathrm{CH}_{2}\right), 5.83-6.02\left(\mathrm{~m}, 3 \mathrm{H}, \mathrm{CH}=\mathrm{CH}_{2}\right), 7.69(\mathrm{~d}, J=7.8 \mathrm{~Hz}, 1 \mathrm{H}, \mathrm{PyH}), 8.03(\mathrm{t}$, $J=7.8 \mathrm{~Hz}, 1 \mathrm{H}, \mathrm{PyH}), 8.21$ (d, $J=7.8 \mathrm{~Hz}, 1 \mathrm{H}, \mathrm{PyH}) \mathrm{ppm} ;{ }^{13} \mathrm{C} \mathrm{NMR}\left(100 \mathrm{MHz}, \mathrm{CD}_{2} \mathrm{Cl}_{2}, 300 \mathrm{~K}\right): \delta=49.1,49.2$, 51.6, 51.8, 54.0, 54.7, 57.9, 66.1, 66.7, 118.9, 119.3,125.3,127.7, 131.1, 134.1, 139.5, 148.2, 151.0, 165.4, 170.0 
ppm ; HRMS (ESI +$) m / z=602.3193(+)\left(\right.$ calculated $m / z=602.3190[\mathrm{M}+\mathrm{H}]^{+}$for $\left.\mathrm{M}=\mathrm{C}_{30} \mathrm{H}_{43} \mathrm{~N}_{5} \mathrm{O}_{8}\right)$.

\subsubsection{DO3Apic-tris(tBu)ester}

Tri-tert-butyl 2,2',2'-(10-((6-(methoxycarbonyl)pyridin-2-yl)methyl)-1,4,7,10-tetraazacyclododecane1,4,7-tri-yl) [69] (0.3 mmol, $200 \mathrm{mg})$ was dissolved in mixture of dioxane $(10 \mathrm{~mL})$ and $1 \mathrm{M}$ aq. $\mathrm{NaOH}(3.4 \mathrm{~mL})$ and stirred for one hour at room temperature. The $\mathrm{pH}$ of the solution was neutralized with TFA and the solvents were removed under reduced pressure. The residue was purified by HPLC to afford DO3Apic-tris(tBu)ester as a white solid (103 mg, $53 \%$ ). ${ }^{1} \mathrm{H}$ NMR (400 MHz, $\mathrm{CDCl}_{3}, 300 \mathrm{~K}$ ): $\delta=1.40$ (s, 18H, $\left.\mathrm{CCH}_{3}\right), 1.48$ (s, 9H, $\mathrm{CCH}_{3}$ ), 2,85-3,85 (br s, $20 \mathrm{H}, \mathrm{NCH}_{2} \mathrm{CH}_{2} \mathrm{~N}+\mathrm{CH}_{2} \mathrm{COO} t \mathrm{Bu}$ ), 3.92 (br s, $2 \mathrm{H}, \mathrm{CH}_{2} \mathrm{COO} t \mathrm{Bu}$ ), 4.56 (br s, $2 \mathrm{H}, \mathrm{CH}_{2} \mathrm{Py}$ ), 7.68 (d, $J=7.8 \mathrm{~Hz}, 1 \mathrm{H}, \mathrm{PyH}), 7.92$ (t, $J=7.8 \mathrm{~Hz}, 1 \mathrm{H}, \mathrm{PyH}), 8.14$ (d, $J=7.8 \mathrm{~Hz}, 1 \mathrm{H}, \mathrm{PyH}) \mathrm{ppm} ;{ }^{13} \mathrm{C}$ NMR $(100 \mathrm{MHz}$, $\left.\mathrm{D}_{2} \mathrm{O}, 353 \mathrm{~K}\right): \delta=30.4,52.2,50.5,50.8,54.6,54.9,57.8,70.0$ 126.4, 130.0, 142.6, 147.8, 152.3, 167.0, 171.7 ppm ; LRMS (ESI + ) monoisotopic $m / z=650.4(+)\left(\right.$ calculated $m / z=650.41[\mathrm{M}+\mathrm{H}]^{+}$for $\left.\mathrm{M}=\mathrm{C}_{33} \mathrm{H}_{55} \mathrm{~N}_{5} \mathrm{O}_{8}\right)$.

\subsection{Peptide synthesis}

\subsubsection{Peptide elongation}

Peptide elongation was performed using standard SPPS procedure using Fmoc/t $\mathrm{Bu}$ chemistry either manually or on an automated peptide synthesizer (CEM Liberty1 Microwave Peptide Synthesizer). Double couplings (30 $\mathrm{min}$ ) were performed using 4-fold molar excess of Fmoc-L-amino acid, 4-fold molar excess of PyBOP and 8-fold molar excess of DIEA at room temperature. A capping step was performed after each coupling with $\mathrm{Ac}_{2} \mathrm{O} /$ DIEA in DMF (5 min). Fmoc removal was performed using $20 \%$ piperidine in DMF ( $\left.2 \times 10 \mathrm{~min}\right)$.

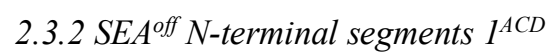

Peptide elongation was performed as described above on SEA-PS resin $(0.1 \mathrm{mmol}, 0.16 \mathrm{mmol} / \mathrm{g})$ after attachment of the first amino acid by double manual coupling $(30 \mathrm{~min})$ using 10-fold excess of Fmoc-Ala-OH, 9.5-fold excess of HATU and 10-fold excess of DIEA in DMF with pre-activation ( $5 \mathrm{~min}$ ) followed by acetylation using $\mathrm{Ac}_{2} \mathrm{O} / \mathrm{DIEA} / \mathrm{DCM}(2: 1: 17 \mathrm{v} / \mathrm{v} / \mathrm{v}, 10 \mathrm{~mL}, 2 \times 5 \mathrm{~min})$ [70]. Fmoc-L-Dap(Alloc)-OH and Fmoc-L-Cys(StBu)$\mathrm{OH}$ amino acid were used to introduce the diaminopropionic acid and cysteine residues, respectively. After acetylation of the N-terminus, removal of the N-Alloc protecting group of the Dap(Alloc) residue was performed by adding to the resin a solution of $\mathrm{Pd}\left(\mathrm{PPh}_{3}\right)_{4}(0.05 \mathrm{mmol}, 0.5$ eq., $58 \mathrm{mg})$ and phenylsilane $(2.5 \mathrm{mmol}, 25$ eq., 0.3 $\mathrm{mL}$ ) in degassed anhydrous DCM $(15 \mathrm{~mL})$ for $1 \mathrm{~h}$ in the dark (twice) [71]. The resin was then washed successively with DCM ( $2 \times 2 \mathrm{~min})$, DMF $(2 \times 2 \mathrm{~min}), 1 \% \mathrm{H}_{2} \mathrm{O}$ in DMF $(2 \times 2 \mathrm{~min})$, DMF $(2 \times 2 \mathrm{~min}), 1 \%$ DIEA in DMF $(2 \times 2$ $\mathrm{min}), \mathrm{DMF}(2 \times 2 \mathrm{~min})$, sodium diethyldithiocarbamate in DMF $(0.12 \mathrm{M}, 2 \times 5 \mathrm{~min})$ and DMF $(2 \times 2 \mathrm{~min})$. A solution of 9-oxo-10(9H)-acridineacetic acid ( $0.2 \mathrm{mmol}, 50.7 \mathrm{mg}, 2$ eq.), PyBOP ( $0.2 \mathrm{mmol}, 104 \mathrm{mg}, 2$ eq.) and DIEA (0.4 mmol, $70 \mu \mathrm{L}, 4$ eq.) in DMF ( $6 \mathrm{~mL}$ ) was prepared and added to the resin. The resin was agitated overnight at room temperature. The resin was washed with DMF $(2 \times 2 \mathrm{~min}), \mathrm{DCM}(2 \times 2 \mathrm{~min})$ and $\mathrm{Et}_{2} \mathrm{O}(2 \times 2 \mathrm{~min})$ and dried. Removal of acid-labile side chain protecting groups and cleavage of the peptidyl resin was performed with TFA $/ \mathrm{H}_{2} \mathrm{O} /$ triisopropylsilane/thioanisole $(92.5: 2.5: 2.5: 2.5 \mathrm{v} / \mathrm{v} / \mathrm{v} / \mathrm{v}, 10 \mathrm{~mL})$ during $2 \mathrm{~h}$. The peptide was then precipitated in ice-cold $\mathrm{Et}_{2} \mathrm{O} /$ heptane $(1: 1 \mathrm{v} / \mathrm{v}, 100 \mathrm{~mL})$, dissolved in $\mathrm{H}_{2} \mathrm{O}$, and lyophilized. The crude peptide was dissolved in $\mathrm{H}_{2} \mathrm{O} / \mathrm{AcOH}$ and treated with a solution of $\mathrm{I}_{2}\left(200 \mathrm{mM}\right.$ in DMSO) to oxidize the C-terminal SEA ${ }^{\text {on }}$ group into SEA ${ }^{\text {off }}$ group [70,72]. After $30 \mathrm{~s}$, DTT $(65 \mathrm{mM}$ in water, $500 \mu \mathrm{L})$ was added to quench the excess of iodine. The oxidized peptide was immediately purified by HPLC to give fragment $\mathbf{1 a}^{\mathbf{A C D}}$ as a powder $(63 \mathrm{mg}$, $38 \%$ yield for the $\mathbf{1}^{\mathrm{ACD}}$. (TFA) 2 salt). HPLC (anal.): $t_{\mathrm{R}}=10.2 \mathrm{~min}$ (method A); ESI-MS: monoisotopic $\mathrm{m} / \mathrm{z}=1431.6$ $(+), 716.3(2+) /$ calculated monoisotopic $m / z=1431.59[\mathrm{M}+\mathrm{H}]^{+}, 716.30[\mathrm{M}+2 \mathrm{H}]^{2+}$ for $\mathrm{M}=\mathrm{C}_{63} \mathrm{H}_{94} \mathrm{~N}_{14} \mathrm{O}_{16} \mathrm{~S}_{4}$. 


\subsubsection{C-terminal segment $2 a$}

Peptide elongation was performed as described above using a peptide synthesizer on Rink-PEG-PS resin (Nova PEG Rink Amide, $0.1 \mathrm{mmol}, 0.45 \mathrm{mmol} / \mathrm{g}$ ) after attachment of the first amino acid by single manual coupling (30 min) using 2-fold excess of Fmoc-Gly-OH, 2-fold excess of PyBOP and 6-fold excess of DIEA in DMF followed by acetylation using $\mathrm{Ac}_{2} \mathrm{O} /$ pyridine/DMF (1:2:7 v/v/v, $\left.10 \mathrm{~mL}, 5 \mathrm{~min}\right)$. Non-standard Fmoc-LLys(Alloc)-OH was used to introduce the Alloc-protected lysine and Boc-L-Cys(Trt)-OH was used as the Nterminal amino acid. Removal of the N-Alloc protecting group of the Lys(Alloc) was performed by adding a solution of $\mathrm{Pd}\left(\mathrm{PPh}_{3}\right)_{4}(0.05 \mathrm{mmol}, 0.5$ eq., $58 \mathrm{mg})$ and phenylsilane $(2.5 \mathrm{mmol}, 25$ eq., $0.3 \mathrm{~mL})$ in degassed anhydrous DCM $(15 \mathrm{~mL})$ for $1 \mathrm{~h}$ in the dark (twice) [71]. The resin was then washed successively with DCM $(2 \times 2$ min), DMF $(2 \times 2 \mathrm{~min}), 1 \% \mathrm{H}_{2} \mathrm{O}$ in DMF $(2 \times 2 \mathrm{~min})$, DMF $(2 \times 2 \mathrm{~min}), 1 \%$ DIEA in DMF $(2 \times 2 \mathrm{~min}), \mathrm{DMF}(2 \times 2$ $\mathrm{min})$, sodium diethyldithiocarbamate in $\operatorname{DMF}(0.12 \mathrm{M}, 2 \times 5 \mathrm{~min})$ and $\mathrm{DMF}(2 \times 2 \mathrm{~min})$. DOTA-tris $(t \mathrm{Bu})$ ester $(0.2$ mmol, $114 \mathrm{mg}, 2$ eq.) was dissolved in a small amount of DMF and added to the resin, then a solution of PyBOP $(0.2 \mathrm{mmol}, 104 \mathrm{mg}, 2$ eq. $)$ and DIEA $(0.6 \mathrm{mmol}, 104 \mu \mathrm{L}, 6 \mathrm{eq})$ in DMF $(2 \mathrm{~mL})$ was added. The resin was agitated overnight at room temperature and the coupling step was repeated once for $4 \mathrm{~h}$. The resin was washed with DMF $(2 \times 2 \mathrm{~min})$, DCM $(2 \times 2 \mathrm{~min})$ and $\mathrm{Et}_{2} \mathrm{O}(2 \times 2 \mathrm{~min})$ and dried. Removal of acid-labile side chain protecting groups and cleavage were performed using TFA $/ \mathrm{H}_{2} \mathrm{O} / \mathrm{TIS} /$ thioanisole $(92.5: 2.5: 2.5: 2.5 \mathrm{v} / \mathrm{v} / \mathrm{v} / \mathrm{v}, 10 \mathrm{~mL})$ for $4 \mathrm{~h}$. The peptide was precipitated in cold $\mathrm{Et}_{2} \mathrm{O} /$ heptane $(1: 1 \mathrm{v} / \mathrm{v}, 150 \mathrm{~mL})$, centrifuged, dissolved in $\mathrm{H}_{2} \mathrm{O}$, lyophilized and purified by HPLC to give $\mathbf{2 a}\left(57 \mathrm{mg}, 21 \%\right.$ yield for the $\mathbf{2 a} \cdot(\mathrm{TFA})_{8}$ salt, $\left.0.1 \mathrm{mmol} \mathrm{scale}\right)$. HPLC (anal.): $t_{\mathrm{R}}=5.4$ min (method A); LRMS (ESI+): average $m / z=1343.3(2+), 895.9(3+), 672.3(4+), 538.0(5+), 448.5(6+) /$ calculated av. $m / z=1343.54[\mathrm{M}+2 \mathrm{H}]^{2+}, 896.03[\mathrm{M}+3 \mathrm{H}]^{3+}, 672.28[\mathrm{M}+4 \mathrm{H}]^{4+}, 538.02[\mathrm{M}+5 \mathrm{H}]^{5+}, 448.52[\mathrm{M}+6 \mathrm{H}]^{6+}$

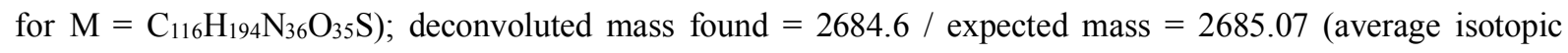
composition).

\subsubsection{C-terminal segment $2 b$}

The beginning of the synthesis was performed as described for 2a on Nova PEG Rink Amide $(0.1 \mathrm{mmol}$, $0.45 \mathrm{mmol} / \mathrm{g}$ ) until removal of the Alloc protecting group. The rest of the synthesis was performed on three tenth of the resin $(0.03 \mathrm{mmol}$ scale). DO3Apic-tris(allyl)ester $(0.06 \mathrm{mmol}, 36 \mathrm{mg}, 2 \mathrm{eq}$. $)$ was dissolved in a small amount of DMF and added to the resin, then a solution of PyBOP (0.06 mmol, $31 \mathrm{mg}, 2$ eq. $)$ and DIEA ( $0.2 \mathrm{mmol}, 35 \mu \mathrm{L}$, 6 eq) in DMF $(2 \mathrm{~mL})$ was added. The resin was agitated overnight at room temperature and the DO3Apictris(allyl)ester coupling step was repeated for $4 \mathrm{~h}$. The resin was washed with DMF $(2 \times 2 \mathrm{~min})$, DCM $(2 \times 2 \mathrm{~min})$. Removal of the allyl protecting groups of the DO3Apic chelate was performed by adding to the resin a solution of $\mathrm{Pd}\left(\mathrm{PPh}_{3}\right)_{4}(0.03 \mathrm{mmol}, 1.0$ eq., $35 \mathrm{mg})$ and phenylsilane $(1.5 \mathrm{mmol}, 50$ eq., $0.18 \mathrm{~mL})$ in degassed anhydrous DCM $(15 \mathrm{~mL})$ for $1 \mathrm{~h}$ in the dark (twice) [71]. The resin was then washed successively with DCM $(2 \times 2 \mathrm{~min})$, DMF $(2 \times 2$ $\mathrm{min}), 1 \% \mathrm{H}_{2} \mathrm{O}$ in DMF $(2 \times 2 \mathrm{~min}), \mathrm{DMF}(2 \times 2 \mathrm{~min}), 1 \%$ DIEA in DMF $(2 \times 2 \mathrm{~min})$, DMF $(2 \times 2 \mathrm{~min})$, sodium diethyldithiocarbamate in DMF $(0.12 \mathrm{M}, 2 \times 5 \mathrm{~min}), \mathrm{DMF}(2 \times 2 \mathrm{~min}), \mathrm{DCM}(2 \times 2 \mathrm{~min})$ and $\mathrm{Et}_{2} \mathrm{O}(2 \times 2 \mathrm{~min})$, then dried. Removal of acid-labile side chain protecting groups and cleavage were performed using TFA $/ \mathrm{H}_{2} \mathrm{O} /$ triisopropylsilane/thioanisole (92.5:2.5:2.5:2.5 v/v/v/v, $10 \mathrm{~mL}$ ) for $2 \mathrm{~h}$. The peptide was precipitated in cold $\mathrm{Et}_{2} \mathrm{O} /$ heptane $(1: 1 \mathrm{v} / \mathrm{v}, 150 \mathrm{~mL})$, centrifuged, dissolved in $\mathrm{H}_{2} \mathrm{O}$, lyophilized and purified by HPLC to give $\mathbf{2 b}$ ( $47 \mathrm{mg}, 37 \%$ yield for the $2 \mathbf{b} \cdot(\mathrm{TFA}){ }_{10}$ salt). HPLC (anal.): $t_{\mathrm{R}}=5.7 \mathrm{~min}$ (method A); LRMS (ESI+): average $\mathrm{m} / \mathrm{z}$ $=921.7(3+), 691.6(4+), 553.4(5+), 461.4(6+) /$ calculated av. $m / z=921.73[\mathrm{M}+3 \mathrm{H}]^{3+}, 691.55[\mathrm{M}+4 \mathrm{H}]^{4+}, 553.44$ $[\mathrm{M}+5 \mathrm{H}]^{5+}, 461.37[\mathrm{M}+6 \mathrm{H}]^{6+}$ for $\left.\mathrm{M}=\mathrm{C}_{121} \mathrm{H}_{197} \mathrm{~N}_{37} \mathrm{O} 35 \mathrm{~S}\right)$; deconvoluted mass found $=2762.0 /$ expected mass $=$ 2762.16 (average isotopic composition).

\subsubsection{Formation of europium complexes $2 a^{E u}$ and $2 b^{E u}$}

Compound 2a/2b $(2.5 \mu \mathrm{mol}, 5 \mathrm{mg})$ was dissolved in $\mathrm{H}_{2} \mathrm{O}$ and the $\mathrm{pH}$ was adjusted to 6.2 using $\mathrm{NaOH}$. Then, the lanthanide salt $\mathrm{EuCl}_{3}(10 \mu \mathrm{mol})$ was added. The solution was stirred overnight under argon (after $1 \mathrm{~h}$, 
the $\mathrm{pH}$ was controlled and adjusted to 6.2 if needed). TCEP $(35 \mu \mathrm{mol}, 10 \mathrm{mg})$ was added prior to removal of excess $\mathrm{Eu}^{3+}$ by HPLC purification. The Eu-loaded peptide was obtained as a white powder after freeze-drying $(90 \%$ yield). $2 \mathbf{a}^{\mathrm{Eu}}$ : HPLC (anal.): $t_{\mathrm{R}}=5.4 \mathrm{~min}(\operatorname{method} \mathrm{A})$; LRMS (ESI+): average $m / z=1417.7(2+), 945.8(3+), 709.6$ $(4+), 567.9(5+) /$ calculated av. $m / z=1418.01[\mathrm{M}+2 \mathrm{H}]^{2+}, 945.68[\mathrm{M}+3 \mathrm{H}]^{3+}, 709.51[\mathrm{M}+4 \mathrm{H}]^{4+}, 567.81[\mathrm{M}+5 \mathrm{H}]^{5+}$ for $\mathrm{M}=\mathrm{C}_{116} \mathrm{H}_{191} \mathrm{~N}_{36} \mathrm{O}_{35} \mathrm{SEu}$ ); deconvoluted mass found $=2834.4 /$ expected mass $=2834.01$ (average isotopic composition). 2 $\mathbf{b}^{\mathrm{Eu}}$ : HPLC (anal.): $t_{\mathrm{R}}=6.1 \mathrm{~min}$ (method A); LRMS (ESI+): average $m / z=971.3(3+), 728.8(4+)$, $583.3(5+) /$ calculated av. $m / z=971.37[\mathrm{M}+3 \mathrm{H}]^{3+}, 728.78[\mathrm{M}+4 \mathrm{H}]^{4+}, 583.23[\mathrm{M}+5 \mathrm{H}]^{5+}$ for $\mathrm{M}=$ $\mathrm{C}_{121} \mathrm{H}_{194} \mathrm{~N}_{37} \mathrm{O}_{35} \mathrm{SEu}$ ); deconvoluted mass found $=2911.2 /$ expected mass $=2911.10$ (average isotopic composition).

\subsubsection{Preparation of LZF probes by native chemical ligation}

A TCEP/MPAA solution was prepared by dissolving TCEP $(28.7 \mathrm{mg}, 0.1 \mathrm{mmol})$ and MPAA (16.8 $\mathrm{mg}$, $0.1 \mathrm{mmol})$ in $0.1 \mathrm{M} \mathrm{pH} 7.5$ sodium phosphate buffer $(1 \mathrm{~mL})$. The $\mathrm{pH}$ of the solution was adjusted to 6.5 using aq. $\mathrm{NaOH}(2 \mathrm{M})$. Peptides $\mathbf{1}^{\mathbf{A C D}}(1.0 \mu \mathrm{mol})$ and $\mathbf{2} \mathbf{a} / \mathbf{b}^{\mathrm{Eu}}(1.1 \mathrm{eq}$.) were dissolved in the TCEP/MPAA solution $(280 \mu \mathrm{L}$, final peptide concentration $3.5 \mathrm{mM}, \mathrm{pH} 6.5$ ). The native chemical ligation was performed at $37^{\circ} \mathrm{C}$ and monitored by HPLC. At the end ( $c a .18-24 \mathrm{~h})$, the reaction mixture was diluted with $5 \%$ aq. TFA $(2 \mathrm{~mL})$, MPAA was

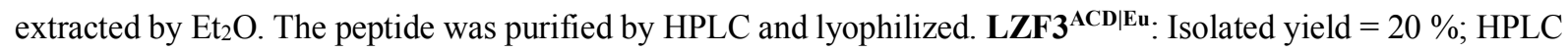
(anal.): $t_{\mathrm{R}}=7.2 \mathrm{~min}(\operatorname{method}$ A); LRMS (ESI+): average $m / z=1348.5(3+), 1011.4(4+), 809.3(5+), 674.8(6+)$, $578.4(7+), 506.4(8+) /$ calculated av. $m / z=1348.46[\mathrm{M}+3 \mathrm{H}]^{3+}, 1011.60[\mathrm{M}+4 \mathrm{H}]^{4+}, 809.48[\mathrm{M}+5 \mathrm{H}]^{5+}, 674.73$ $[\mathrm{M}+6 \mathrm{H}]^{6+}, 578.49[\mathrm{M}+7 \mathrm{H}]^{7+}, 506.30[\mathrm{M}+8 \mathrm{H}]^{8+}$ for $\mathrm{M}=\mathrm{C}_{171} \mathrm{H}_{268} \mathrm{~N}_{49} \mathrm{O} \mathrm{O}_{51} \mathrm{~S}_{2} \mathrm{Eu}$; deconvoluted mass found $=4041.8$ $/$ expected mass $=4042.36$ (average isotopic composition). LZF4 $^{\mathbf{A C D} \mid \mathbf{E u}}$ : Isolated yield $=41 \%$; HPLC (anal.): $t_{\mathrm{R}}$ $=7.5 \mathrm{~min}(\mathrm{method}$ A); LRMS (ESI+): average $\mathrm{m} / z=1373.9(3+), 1030.8(4+), 824.9(5+), 687.7(6+), 589.6(7+)$, $516.0(8+) /$ calculated av. $m / z=1374.16[\mathrm{M}+3 \mathrm{H}]^{3+}, 1030.87[\mathrm{M}+4 \mathrm{H}]^{4+}, 824.90[\mathrm{M}+5 \mathrm{H}]^{5+}, 687.58[\mathrm{M}+6 \mathrm{H}]^{6+}$, $589.50[\mathrm{M}+7 \mathrm{H}]^{7+}, 515.94[\mathrm{M}+8 \mathrm{H}]^{8+}$ for $\mathrm{M}=\mathrm{C}_{176} \mathrm{H}_{271} \mathrm{~N}_{50} \mathrm{O}_{51} \mathrm{~S}_{2} \mathrm{Eu}$; deconvoluted mass found $=4119.4 /$ expected mass $=4119.44$ (average isotopic composition). Chromatograms and MS spectra of purified $\mathbf{L Z F}^{\mathbf{A C D} \mid \mathbf{E u}}$ and $\mathbf{L Z F 4}^{\mathbf{A C D} \mid \mathbf{E u}}$ compounds are provided in Fig. S1 of ESI.

\subsection{Luminescence spectroscopy}

\subsubsection{Measurements}

All measurements were performed using aerated solutions. Emission and excitation spectra were measured on a Varian Cary Eclipse spectrometer equipped with a thermo-regulated cell holder or on a modular Fluorolog FL3-22 spectrometer from Horiba-Jobin Yvon-Spex equipped with a double-grating excitation monochromator and an iHR320 imaging spectrometer coupled to an R928P Hamamatsu photomultiplier. Emission spectra were corrected for wavelength-dependant detector response. Time-gated $\mathrm{Eu}^{3+}$ luminescence spectra were acquired with $100 \mu$ s time delay and $2 \mathrm{~ms}$ gate time. $\mathrm{Eu}^{3+}$ luminescence lifetimes were measured using the Varian Cary Eclipse spectrometer. Quantum yields of europium emission of LZF probes were determined using the Fluorolog spectrometer by a relative method with quinine sulphate in $0.5 \mathrm{M} \mathrm{H}_{2} \mathrm{SO}_{4}$ as standard [73,74]. Estimated experimental error for the quantum yield determination is $\sim 10 \%$.

\subsubsection{Sample preparation and $\mathrm{Zn}^{2+}$ titrations}

All samples were prepared in a HEPES buffer $(10 \mathrm{mM}, \mathrm{pH}$ 7.5) containing TCEP as reducing agent $(250 \mu \mathrm{M}) . \mathrm{Zn}^{2+}$ titrations were performed using a $\mathrm{Zn}\left(\mathrm{ClO}_{4}\right)_{2}$ solution $\left(1.00 \mathrm{mM}\right.$ in $\left.\mathrm{H}_{2} \mathrm{O}\right)$.

\subsubsection{Determination of europium hydration number $q$}

Solutions of the LZF probes in a HEPES buffer $(10 \mathrm{mM}, \mathrm{pH} 7.5)$ containing TCEP $(250 \mu \mathrm{M})$ were 
prepared in various $\mathrm{H}_{2} \mathrm{O} / \mathrm{D}_{2} \mathrm{O}$ mixtures $\left(25,50,75\right.$ and $\left.100 \% \mathrm{H}_{2} \mathrm{O}\right)$. Lifetimes were obtained by mono-exponential fit of the $\mathrm{Eu}^{3+}$ emission decay (Table 1). Margin of error on lifetimes is estimated to be $0.01 \mathrm{~ms}$ from three measurements. Lifetimes in $100 \% \mathrm{D}_{2} \mathrm{O}$ were extrapolated from the plot of the rate constants of $\mathrm{Eu}^{3+}$ luminescence decay $\left(k_{\mathrm{Eu}}=\tau_{\mathrm{Eu}^{-1}}{ }^{-1}\right)$ against the fraction of $\mathrm{H}_{2} \mathrm{O}$ in $\mathrm{H}_{2} \mathrm{O} / \mathrm{D}_{2} \mathrm{O}$ mixtures (Fig S2 of ESI and Table 1). The number of coordinated water molecules $(q)$ was determined using $q=1.2 \times\left(k_{\mathrm{Eu} / \mathrm{H} 2 \mathrm{O}}-k_{\mathrm{Eu} / \mathrm{D} 2 \mathrm{O}}-0.325\right)$ for $\mathrm{Eu}^{3+}[75]$.

\subsection{Determination of $\mathrm{Zn}^{2+}$ binding constants}

Binding constants were determined by titrating a solution containing the LZF probe and a known amount of an appropriate competitor, as previously described $[51,66]$. For both probes, EDTA and HEDTA were found to be too strong competitors and the binding constants were determined using EGTA. Time-gated $\mathrm{Eu}^{3+} \mathrm{emission}$ was used to monitor the titration. Titration curves were fitted to the equilibrium Zn·LZF + EGTA $\rightleftharpoons \mathrm{LZF}+\mathrm{Zn} \cdot \mathrm{EGTA}$ using the apparent $\mathrm{Zn}^{2+}$ binding constant of EGTA at $\mathrm{pH} 7.5$ was calculated from $\mathrm{p} K_{\mathrm{a}}$ and $\log \beta_{11}$ values reported in the literature: $K_{\mathrm{ZnEGTA}}=10^{9.2}[76,77]$. The $\mathrm{Zn}^{2+}$ titrations in the presence of EGTA and their fits are shown in Fig. S3 of ESI.

\section{Results and discussion}

\subsection{Design and synthesis of $\mathrm{Eu}^{3+}$-based $\mathrm{Zn}^{2+}$-responsive probes}

In order to improve the properties of the previously described $\mathrm{Eu}^{3+}$-based $\mathrm{Zn}^{2+}$-responsive probe

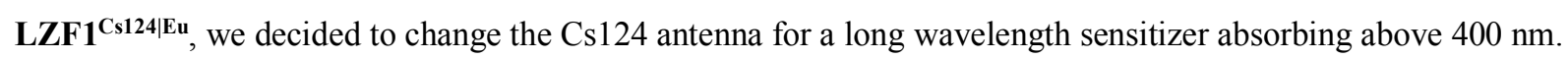
The number of suitable antennas reported in the literature is rather limited [78-80] and acridone, which has been used in several DO3A-Eu ${ }^{3+}$ complexes [46,81-83], appeared to be the best choice. Additionally, 9-oxo-10(9H)acridineacetic acid, a carboxylate derivative, that can be readily coupled to a peptide, is commercially available. Keeping the design and sequence of the previously described LZF $1^{\text {antennalLn }}$ probes [51], we synthetized a first probe, LZF3 ${ }^{\mathbf{A C D} \mid \mathbf{E u}}$, that features an acridone antenna and a DOTA-Eu ${ }^{3+}$ complex at the same position in the sequence. As the previous probes, this one was obtained by SEA native chemical ligation of a N-terminal segment, $\mathbf{1}^{\mathrm{ACD}}$, bearing the acridone moiety, and a C-terminal segment, $\mathbf{2 a}^{\mathrm{Eu}}$, bearing a DOTA-Eu ${ }^{3+}$ complex (Fig. 1). The synthesis of $\mathbf{2 a}^{\mathbf{E u}}$ (Fig. 2) involves the coupling of DOTA-tris( $t$ Bu)ester on a selectively deprotected lysine side chain of resin-bound peptide $\mathbf{2}$ and subsequent removal of the DOTA carboxylate $t \mathrm{Bu}$ protecting groups during acidic cleavage of the peptide to afford $\mathbf{2 a}$, which is then converted into $\mathbf{2} \mathbf{a}^{\mathbf{E u}}$ by metalation with $\mathrm{Eu}^{3+}$ in water. The main drawback of the DOTA ligand regarding luminescence properties is that it leaves $\mathrm{Ln}^{3+}$ coordinatively unsaturated with its four nitrogen and four oxygen donors, allowing one water molecule in the $\mathrm{Ln}^{3+}$ coordination sphere. In order to investigate the effect of a nonadentate $v$ s octadente chelate, we decided to use a DO3Apic ligand, which differs from the DOTA by the replacement of a monodentate acetate arm by a bidentate picolinate arm. $\mathrm{Ln}^{3+}$ complexes of DO3Apic ligands have been reported to be coordinatively saturated $[69,84,85]$ while

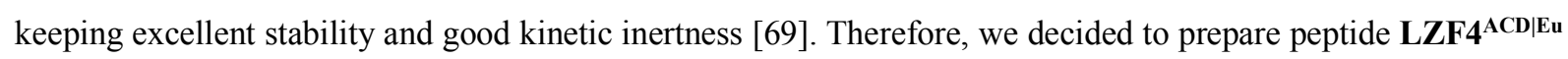
from $\mathbf{1}^{\mathbf{A C D}}$ and segment $\mathbf{2} \mathbf{b}^{\mathrm{Eu}}$, displaying a DO3Apic ligand (Fig. 1). As for $\mathbf{2} \mathbf{a}^{\mathrm{Eu}}$, the synthesis of $\mathbf{2} \mathbf{b}^{\mathrm{Eu}}$ requires a building block with protected acetate arms and free picolinic carboxylic acid. 

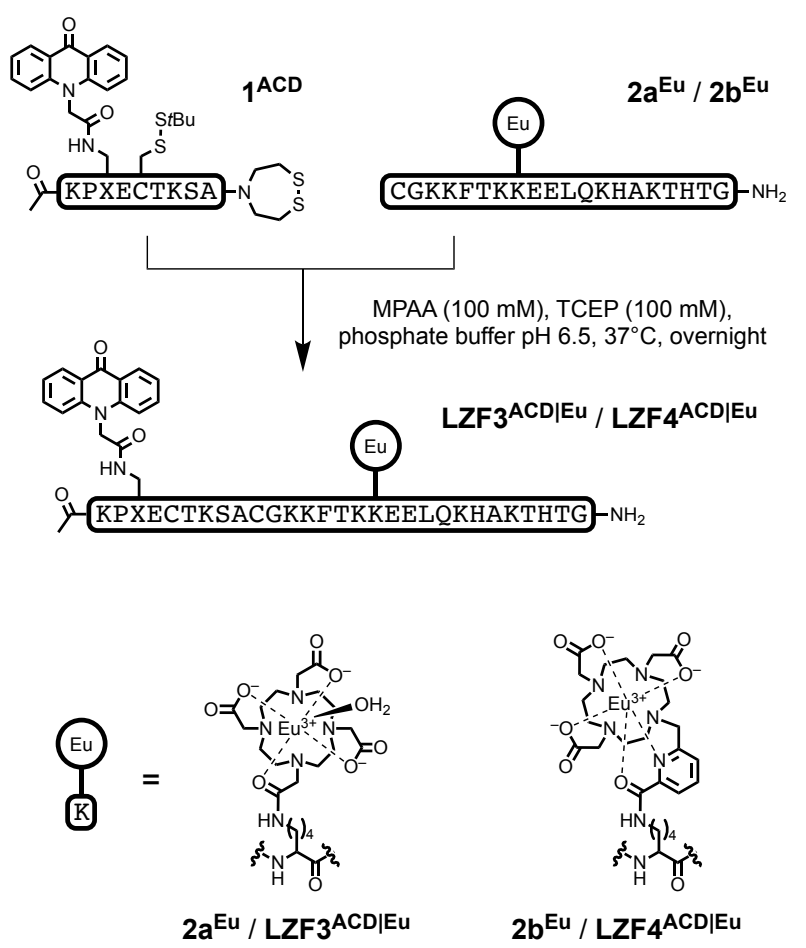

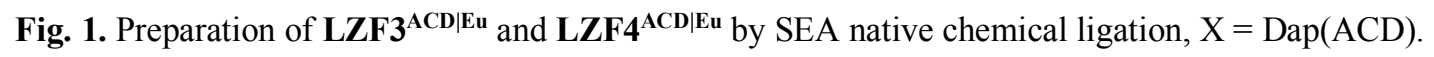

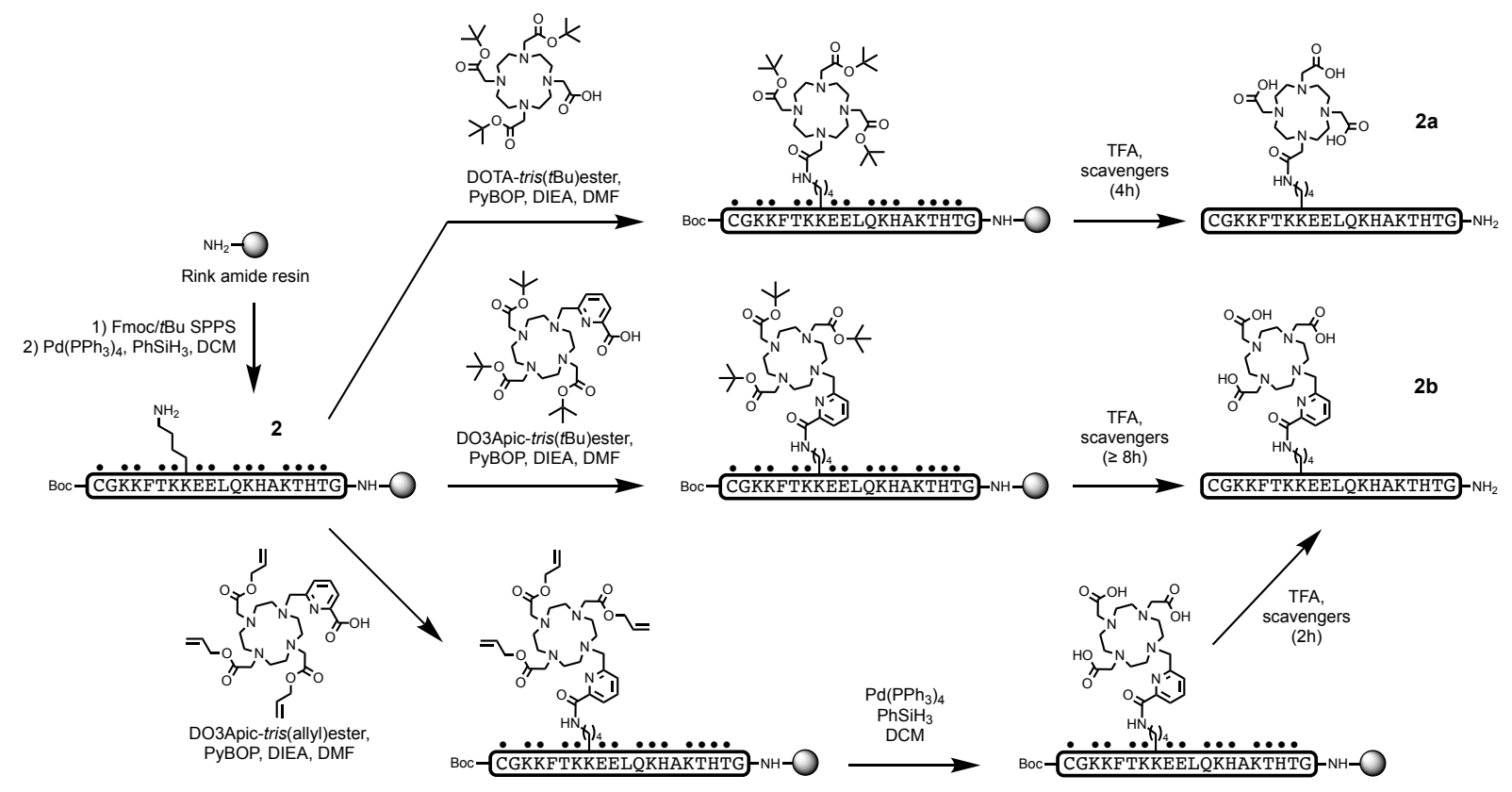

Fig. 2. Synthetic pathways for the preparation of $\mathbf{2} \mathbf{a}$ and $\mathbf{2} \mathbf{b}$. $\cdot$ denotes standard side chain protecting group (Boc for Lys; $t \mathrm{Bu}$ for Glu, and Thr; Trt for Cys, Gln and His).

First, we examined DO3Apic-tris $(t \mathrm{Bu})$ ester, with $t \mathrm{Bu}$ protecting groups for acetates, as a building block for DO3Apic conjugation (Fig. 2). It can be obtained by reaction of DO3A-tris $(t \mathrm{Bu})$ ester (commercially available) with methyl-6-chloromethylpicolinate [69] followed by hydrolysis of the picolinate methyl ester in basic conditions. DO3Apic-tris $(t \mathrm{Bu})$ ester was coupled to resin-bound peptide 2 using PyBOP and DIEA in DMF (Fig. 2). The resin was then submitted to TFA/ $\mathrm{H}_{2} \mathrm{O} / \mathrm{TIS} /$ thioanisole treatment for $4 \mathrm{~h}$ to cleave the peptide and remove 
protecting groups and the crude was analysed by HPLC and mass spectrometry (Fig. 4). 2b was identified as eluting at $5.7 \mathrm{~min}$ on the chromatogram but several other peaks of similar height were also observed that were identified as peptides still bearing one (at 6.2 and $7.0 \mathrm{~min}$ ), two (at $8.6 \mathrm{~min}$ ) or three $t \mathrm{Bu}$ groups (at $10.7 \mathrm{~min}$ ), revealing incomplete removal of the DOA3pic $t \mathrm{Bu}$ protecting groups. Compounds with one or two $t \mathrm{Bu}$ could still be observed upon extending the TFA/scavengers treatment to $8 \mathrm{~h}$ but they almost disappear after $16 \mathrm{~h}$ TFA/scavengers treatment. Removal of $t \mathrm{Bu}$ protecting groups of DOTA-tris $(\mathrm{tBu})$ ester conjugated to peptides is known to be slow [86,87]. To reach completion, it generally requires $\geq 4 \mathrm{~h}$ TFA/scavengers treatment or a $2 \mathrm{~h}$ TFA/scavenger treatment but followed by a neat TFA treatment [86]. The kinetic of acidolitic removal of $t \mathrm{Bu}$ groups seems to be even slower for DO3Apic-tris $(t \mathrm{Bu})$ ester.

In the case of DOTA, a solution to this problem was the use of allyl protecting groups instead of $t \mathrm{Bu}$, which are readily removed by $\mathrm{Pd}^{0}$ treatment on resin before TFA/scavenger treatment [87]. Therefore, we decided to change the $t$ Bu protection groups for allyl and prepared DO3Apic-tris(allyl)ester. This compound was obtained by solid phase synthesis (Fig. 3). First, 6-(chloromethyl)picolinic acid was grafted on 2-chlorotrityl chloride resin. Then, an excess of cyclen was reacted and the resin-bound macrocycle was subsequently alkylated using an excess of allyl chloroacetate. The final product was cleaved from the resin in mild conditions (TFE/DCM 2:3) and DO3Apic-tris(allyl)ester was obtained in $46 \%$ overall yield after HPLC purification. This building block was then coupled to resin-bound peptide 2 (Fig. 2) using PyBOP activation of the picolinic acid and then the resin was treated with $\mathrm{Pd}^{0} /$ phenylsilane for allyl removal. After $2 \mathrm{~h}$ TFA/ $\mathrm{H}_{2} \mathrm{O} / \mathrm{TIS} /$ thioanisole treatment, the crude peptide mixture was analysed by HPLC (Fig. 4). The chromatogram shows $\mathbf{2} \mathbf{b}$ as the major product with no trace of allylcontaining peptides, indicating that the $\mathrm{Pd}^{0}$ treatments allows complete removal of allyl groups. Noteworthy, the HPLC trace shows less impurity than the one obtained for DO3Apic-tris( $t \mathrm{Bu})$ ester after $16 \mathrm{~h} \mathrm{TFA} /$ scavenger treatment. Therefore, the allyl-protected building block is superior to the $t$ Bu-protected building block to graft a DO3Apic moiety onto a peptide.

Metalation of $\mathbf{2 b}$ with $\mathrm{Eu}^{3+}$ in $\mathrm{H}_{2} \mathrm{O}$ at $\mathrm{pH} 6.2$ affords $\mathbf{2} \mathbf{b}^{\mathbf{E u}}$. $\mathrm{Ln}^{3+}$ complexes of DO3Apic ligands are known to present good kinetic and thermodynamic stabilities [69]. The picolinate oxygen atom occupies a labile capping position in the coordination sphere. Changing the negatively charged carboxylate of the picolinate into an neutral amide was anticipated to result in a weaker coordination. Nevertheless, $\mathbf{2} \mathbf{b}^{\mathrm{Eu}}$ is stable enough to resist the acid conditions $(\mathrm{pH} \approx 2$ ) of the HPLC purification. This may be ascribed to a lower propensity to acid-catalyzed dissociation in the case of the neutral amide compared to the negatively charged carboxylate. Finally, LZFF4 $4^{\mathrm{ACD} \mid \mathbf{E u}}$ bearing a DO3Apic-Eu complex was assembled from $\mathbf{1}^{\mathbf{A C D}}$ and $\mathbf{2} \mathbf{b}^{\mathrm{Eu}}$ by SEA native chemical ligation. 
A

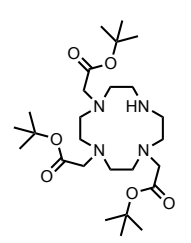

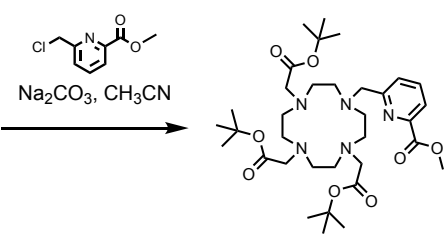

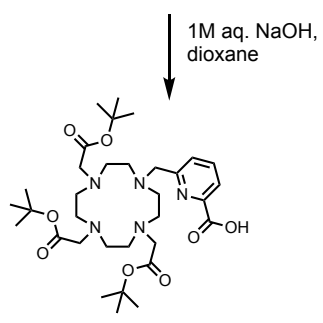

DO3Apic-tris(tBu)ester

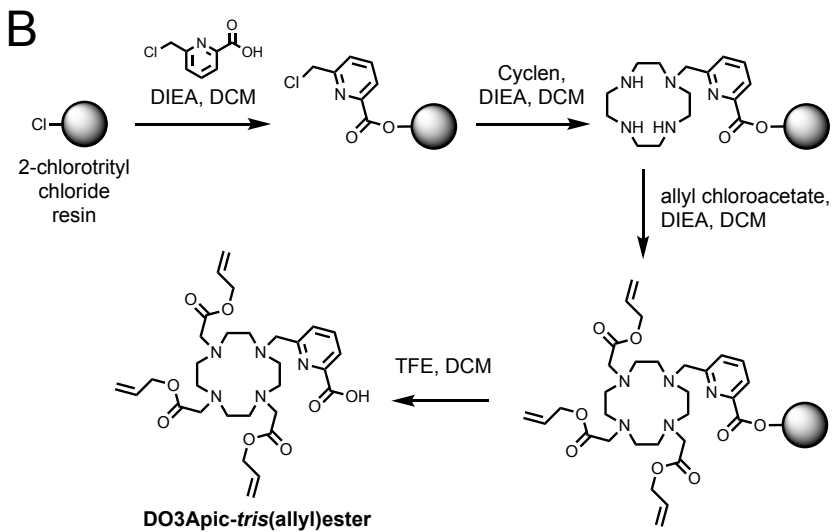

Fig. 3. Synthetic pathway for the preparation of (A) DO3Apic-tris(tBu)ester and (B) DO3Apic-tris(allyl)ester.

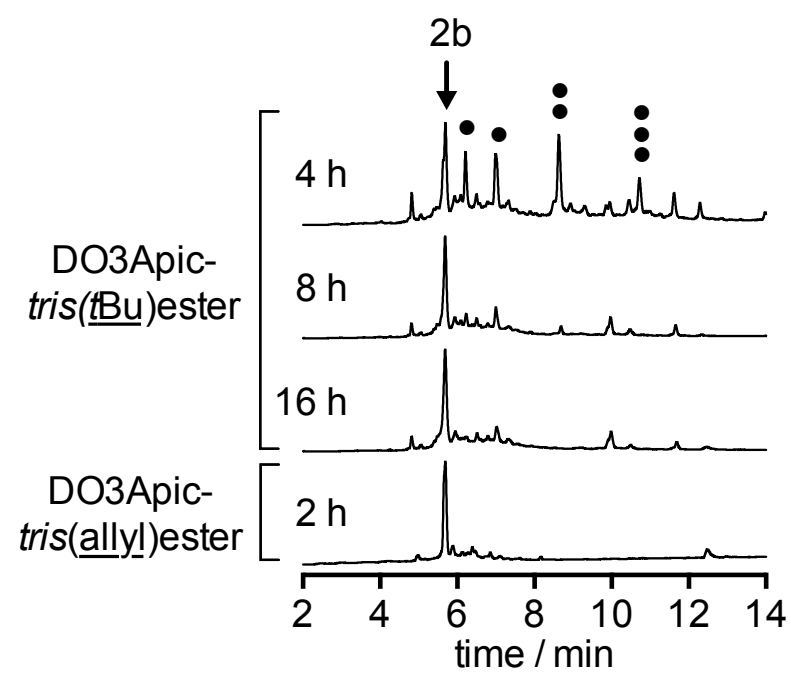

Fig. 4. HPLC chromatograms (absorbance at $214 \mathrm{~nm}$ ) obtained after the final TFA/scavengers treatment of the resin-bound peptide (crude mixture) for the synthesis of $\mathbf{2 b}$ (retention time $=5.7 \mathrm{~min}$ ) using DO3Apictris $(t \mathrm{Bu})$ ester and DO3Apic-tris(allyl)ester. The duration of the TFA treatment is indicated. Peaks labelled with black dots correspond to peptide $\mathbf{2} \mathbf{b}$ with incomplete removal of $t$ Bu groups, the number of dots indicating the number of remaining $t \mathrm{Bu}$. 


\subsection{Spectroscopic characterization of $L Z F 3^{A C D \mid E u}$ and $L Z F 4^{A C D \mid E u}$}

The spectroscopic properties of $\mathbf{L Z F 3}^{\mathbf{A C D} \mid \mathbf{E u}}$ and $\mathbf{L Z F} 4^{\mathbf{A C D} \mid \mathbf{E u}}$ were investigated in HEPES buffer $(10 \mathrm{mM}$, $\mathrm{pH}$ 7.5) containing TCEP as a reductant to prevent formation of disulfides. As seen on the absorption spectrum of LZF3 $^{\text {ACD|Eu }}$, featuring the DOTA-Eu ${ }^{3+}$ complex, the acridone chromophore display an absorption band in the UV $\left(\lambda_{\max }=256 \mathrm{~nm}\right)$ as well as two bands in the visible at $388 \mathrm{~nm}$ and $402 \mathrm{~nm}$ extending up to $430 \mathrm{~nm}$ (Fig. 5A, left).

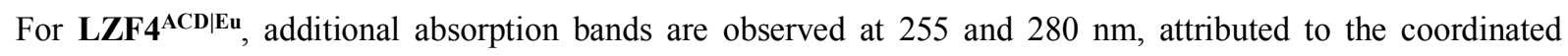
picolinamide chromophore (Fig. 5A, right) [69]. First, we examined the luminescence properties of $\mathbf{L Z F} 3^{\mathbf{A C D} \mid \mathbf{E u}}$. Upon excitation at $402 \mathrm{~nm}$, the time-gated emission spectrum (100 $\mu$ s delay) display bands at 580, 590, 615, 650 and $700 \mathrm{~nm}$ characteristic of the ${ }^{5} \mathrm{D}_{0} \rightarrow{ }^{7} \mathrm{~F}_{J}(J=0,1,2,3,4)$ transitions of $\mathrm{Eu}^{3+}$ (Fig. 5C). The excitation spectrum of $\mathrm{Eu}^{3+}$ luminescence matches the absorption spectrum of the acridone moiety (Fig. 5B), indicating that it sensitizes $\mathrm{Eu}^{3+}$ in this system. The lifetime of $\mathrm{Eu}^{3+}$ luminescence $\left(\tau_{\mathrm{Eu}}\right)$, which corresponds to the ${ }^{5} \mathrm{D}_{0}$ excited state lifetime, is $0.63 \mathrm{~ms}$ (Table 1). The $\mathrm{Eu}^{3+}$ hydration number $(q)$ was determined to be 1 in agreement with the octadentate DOTA ligand leaving space for a single water molecule in the coordination sphere of $\mathrm{Eu}^{3+}$. Upon addition of $\mathrm{Zn}^{2+}$, the $\mathrm{Eu}^{3+}$ emission increases until 1.0 eq. of $\mathrm{Zn}^{2+}$ is added and plateaus above this stoichiometry (Fig. 5D), indicating the formation of a 1:1 $\mathrm{Zn}^{2+} / \mathbf{L Z F 3}^{\mathbf{A C D} \mid \mathbf{E u}}$ complex. Overall, $\mathrm{Eu}^{3+}$ emission increases 6.2-fold upon $\mathrm{Zn}^{2+}$ binding. The absence of change in the $\mathrm{Eu}^{3+}$ emission spectrum upon $\mathrm{Zn}^{2+}$ binding (Fig. S4 of ESI) indicates that $\mathrm{Eu}^{3+}$ coordination is the same in $\mathbf{L Z F 3}^{\mathbf{A C D} \mid \mathbf{E u}}$ and $\mathrm{Zn} \cdot \mathbf{L Z F}^{\mathbf{A C D} \mid \mathbf{E u}}$. Additionally, both $\tau_{\mathrm{Eu}}$ and $q$ remain unchanged upon $\mathrm{Zn}^{2+}$ binding (Table 1). All this suggests that the enhancement of $\mathrm{Eu}^{3+}$ emission is solely due to a shortening of the distance between the acridone antenna and $\mathrm{Eu}^{3+}$ as a consequence of peptide folding. Finally, the dissociation constant of the $\mathrm{Zn} \cdot \mathbf{L Z F 3}^{\mathbf{A C D} \mid \mathbf{E u}}$ complex was determined to be $10^{-10.1} \mathrm{M}$ by a $\mathrm{Zn}^{2+}$ titration in competition with EGTA, a chelator with known affinity for $\mathrm{Zn}^{2+}$. 

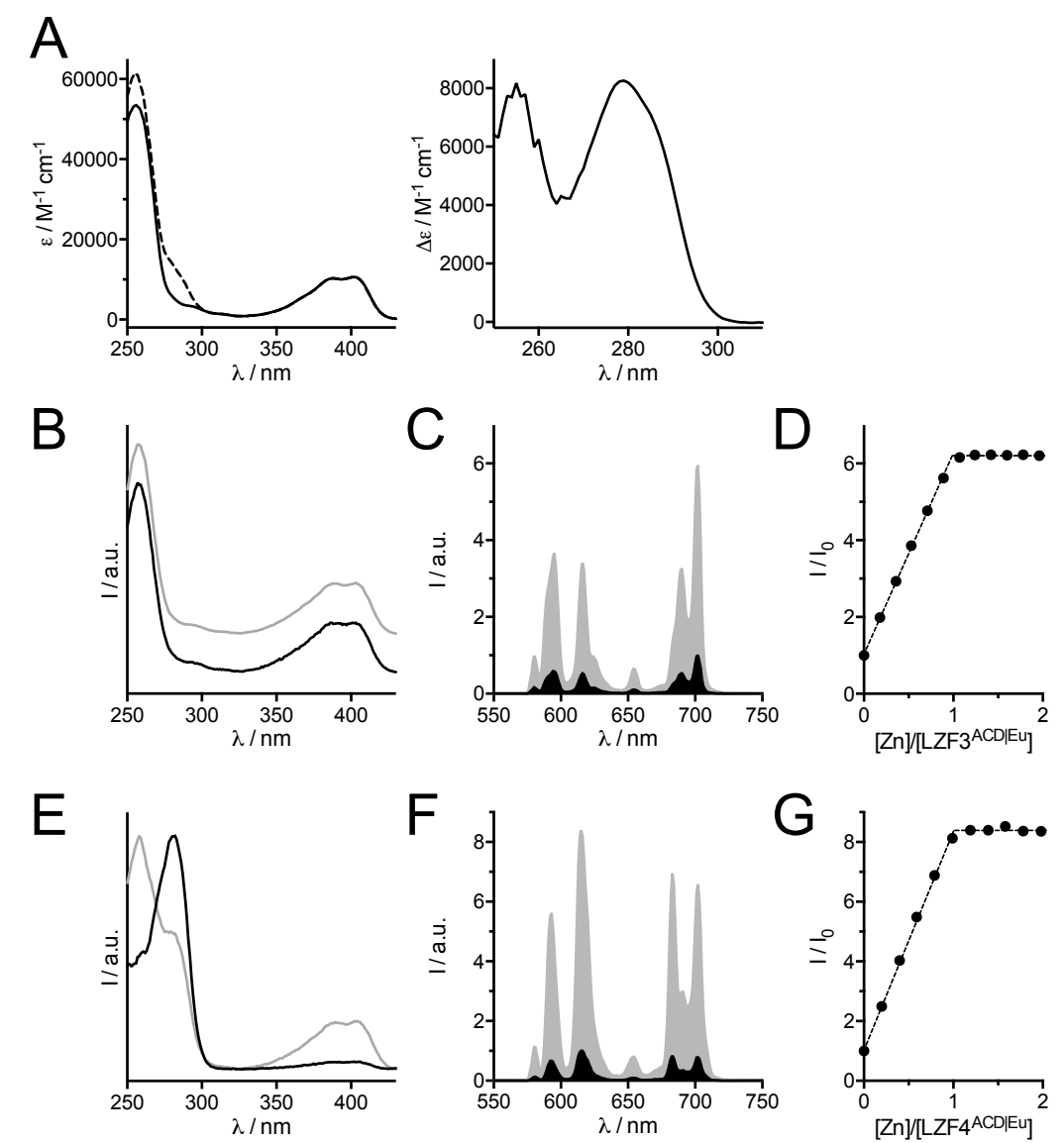

Fig. 5. Spectroscopic properties. (A) Left: Absorption spectrum of $\mathbf{L Z F 3} 3^{\mathbf{A C D} \mid \mathbf{E u}}$ (solid line) and $\mathbf{L Z F} 4^{\mathbf{A C D} \mid \mathbf{E u}}$ (dashed line). Right: Differential absorption spectrum $\Delta \varepsilon=\varepsilon\left(\mathbf{L Z F} 4^{\mathbf{A C D} \mid \mathbf{E u}}\right)-\varepsilon\left(\mathbf{L Z F} 3^{\mathbf{A C D} \mid \mathbf{E u}}\right)$ showing the extra

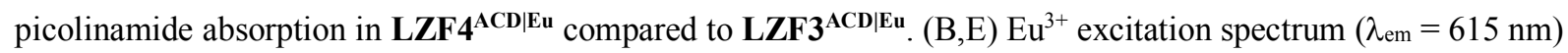
of $\mathbf{L Z F 3}^{\mathbf{A C D} \mid \mathbf{E u}}$ (B) and $\mathbf{L Z F 4} 4^{\mathbf{A C D} \mid \mathbf{E u}}$ (E) in their Zn-free (black) and Zn-bound (grey) forms. (C,F) Time-gated Eu ${ }^{3+}$ emission spectrum $\left(\lambda_{\text {ex }}=402 \mathrm{~nm}\right.$ ) of $\mathbf{L Z F 3}^{\mathbf{A C D} \mid \mathbf{E u}}(\mathrm{C})$ and $\mathbf{L Z F 4} 4^{\mathrm{ACD} \mid \mathbf{E u}}$ (F) in their Zn-free (black) and Zn-bound (grey) forms. (D,G) Evolution of integrated $\mathrm{Eu}^{3+}$ emission during the $\mathrm{Zn}^{2+}$ titration of $\mathbf{L Z F 3}{ }^{\mathbf{A C D} \mid \mathbf{E u}}$ (D) and LZF4 $^{\mathbf{A C D} \mid \mathbf{E u}}(\mathrm{G})$. All solutions were prepared with $10 \mu \mathrm{M}$ probe in aerated HEPES buffer $(10 \mathrm{mM}, \mathrm{pH} 7.5)$ containing TCEP $(250 \mu \mathrm{M})$.

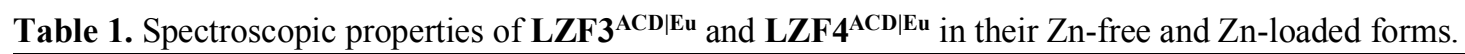

\begin{tabular}{llllllll}
\hline Compound & $\tau_{\mathrm{Eu}} / \mathrm{ms}\left(\mathrm{H}_{2} \mathrm{O} / \mathrm{D}_{2} \mathrm{O}\right)$ & $\tau_{\mathrm{R}} / \mathrm{ms}$ & $q( \pm 0.3)$ & $\Phi_{\mathrm{Eu}}^{\mathrm{ACD}} / \%^{\mathrm{a}}$ & $\eta_{\mathrm{sens}}^{\mathrm{ACD}} / \%^{\mathrm{a}}$ & $\Phi_{\mathrm{Eu}}^{\mathrm{Eu}} / \%$ & $\Phi_{\mathrm{Eu}}^{\mathrm{pic}} / \% \mathrm{o}$ \\
\hline $\mathbf{L Z F 3}^{\mathrm{ACD} \mid \mathbf{E u}}$ & $0.63 / 2.41$ & 6.79 & 1.0 & 0.06 & 0.6 & 9.3 & - \\
$\mathbf{Z n} \cdot \mathbf{L Z F 3} 3^{\mathrm{ACD} \mid \mathbf{E u}}$ & $0.64 / 2.35$ & 6.77 & 1.0 & 0.35 & 3.7 & 9.5 & - \\
$\mathbf{L Z F 4}^{\mathbf{A C D} \mid \mathbf{E u}}$ & $1.02 / 1.53$ & 4.95 & 0.0 & 0.16 & 0.8 & 20.5 & 4.2 \\
$\mathbf{Z n}^{\mathrm{L}} \mathbf{L Z F 4} 4^{\mathrm{ACD} \mid \mathbf{E u}}$ & $1.10 / 1.73$ & 4.98 & 0.0 & 1.3 & 5.9 & 22.0 & 4.2 \\
\hline
\end{tabular}

${ }^{\mathrm{a}} \lambda_{\mathrm{ex}}=368 \mathrm{~nm} .{ }^{\mathrm{b}} \lambda_{\mathrm{ex}}=283 \mathrm{~nm}$.

A quite similar behavior is observed for the other probe, $\mathbf{L Z F} 4^{\mathbf{A C D} \mid \mathbf{E u}}$, with the DO3Apic-Eu ${ }^{3+}$ complex. Excitation of the acridone chromophore at $402 \mathrm{~nm}$ promotes $\mathrm{Eu}^{3+}$ emission and, as for $\mathbf{L Z F 3}{ }^{\mathbf{A C D} \mid \mathbf{E u}}$, addition of $\mathrm{Zn}^{2+}$ to $\mathbf{L Z F 4}{ }^{\mathbf{A C D} \mid \mathbf{E u}}$ induces an 8.4-fold increase of $\mathrm{Eu}^{3+}$ emission (Fig. 5G) upon formation of the 1:1 $\mathrm{Zn} \cdot \mathbf{L Z F 3}^{\mathbf{A C D} \mid \mathbf{E u}}$ complex $\left(K_{\mathrm{d}}=10^{-9.9} \mathrm{M}\right)$. This $\mathrm{Zn}^{2+}$-induced increase of $\mathrm{Eu}^{3+}$ emission intensity is slightly larger

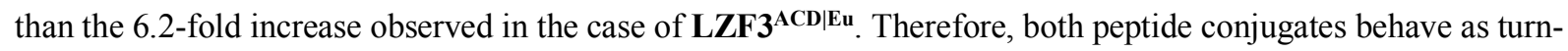


on responsive probes for $\mathrm{Zn}^{2+}$ but several differences can be noted as a consequence of the substitution of DOTA for DO3Apic. First, in both Zn-free and Zn-bound forms, $\mathbf{L Z F} 4^{\mathbf{A C D} \mid \mathbf{E u}}$ displays higher $\mathrm{Eu}^{3+}$ luminescence lifetime (ca. $1.0 \mathrm{~ms} v s 0.63 \mathrm{~ms}$, Table 1) and it has no water molecule bound to $\mathrm{Eu}^{3+}(q=0)$, in agreement with a nonadentate chelation for DO3Apic, as expected. This translates into different $\mathrm{Eu}^{3+}$ emission profiles: the intensity ratios of the various ${ }^{5} \mathrm{D}_{0} \rightarrow{ }^{7} \mathrm{~F}_{J}$ transitions are altered due to a different symmetry around the $\mathrm{Eu}^{3+}$ (Fig. 5C and F). Another difference can be seen in the $\mathrm{Eu}^{3+}$ excitation spectra (Fig. 5B and E). The one of Zn-free $\mathbf{L Z F} \mathbf{4}^{\mathbf{A C D} \mid \mathbf{E u}}$ is dominated by a band at $283 \mathrm{~nm}$, which corresponds to the picolinamide chromophore but bands corresponding to the acridone chromophore are also present. This indicates that both acridone and picolinamide chromophores can sensitize $\mathrm{Eu}^{3+}$ emission, with the latter coordinated to $\mathrm{Eu}^{3+}$ being a more efficient antenna. Inspection of the $\mathrm{Eu}^{3+}$ excitation spectrum of $\mathrm{Zn}^{2+}$-bound $\mathbf{L Z F} 4^{\mathbf{A C D} \mid \mathbf{E u}}$ shows a larger contribution of the acridone chromophore relative to the $\mathrm{Zn}$ free form. Finally, $\mathbf{L Z F} 4^{\mathbf{A C D} \mid \mathbf{E u}}$ displays better quantum yields of sensitized $\mathrm{Eu}^{3+}$ luminescence upon excitation of the acridone antenna $\left(\Phi_{\mathrm{Eu}}^{\mathrm{ACD}}\right)$, both in the $\mathrm{Zn}$-free and $\mathrm{Zn}$-bound forms (Table 1). Indeed, changing the DOTA for DO3Apic allows doubling the quantum yield of the Zn-bound form, but these quantum yields are rather low, whatever the ligand.

Among $\mathrm{Ln}^{3+}, \mathrm{Eu}^{3+}$ is particularly interesting because metal-centered luminescence quantum yield, $\Phi_{\mathrm{Eu}}^{\mathrm{Eu}}$, can be determined directly from the emission spectrum [88] using equation (1), where $\tau_{\mathrm{R}}$ is the radiative lifetime of $\mathrm{Eu}^{3+}$, which can be calculated with equation (2).

$$
\begin{aligned}
& \Phi_{\mathrm{Eu}}^{\mathrm{Eu}}=\tau_{\mathrm{Eu}} / \tau_{\mathrm{R}} \\
& 1 / \tau_{\mathrm{R}^{-1}}=A_{\mathrm{MD}, 0} \times n^{3} \times\left(I_{\mathrm{tot}} / I_{\mathrm{MD}}\right)
\end{aligned}
$$

$A_{\mathrm{MD}, 0}$ is the spontaneous emission probability for the ${ }^{5} \mathrm{D}_{0} \rightarrow{ }^{7} \mathrm{~F}_{1}$ transition and it is calculated to be $14.65 \mathrm{~s}^{-1}, n$ is the refractive index of the medium and $I_{\text {tot }}$ and $I_{\mathrm{MD}}$ are the total area of the corrected $\mathrm{Eu}^{3+}$ emission spectrum and the area of the ${ }^{5} \mathrm{D}_{0} \rightarrow{ }^{7} \mathrm{~F}_{1}$ transition band, respectively. The sensitization efficiency, $\eta_{\mathrm{sens}}^{\mathrm{ACD}}$, which quantifies the energy transfer process between the antenna and $\mathrm{Eu}^{3+}$ can be determined from $\Phi_{\mathrm{Eu}}^{\mathrm{ACD}}$ and $\Phi_{\mathrm{Eu}}^{\mathrm{Eu}}$ by equation (3).

$$
\Phi_{\mathrm{Eu}}^{\mathrm{ACD}}=\eta_{\mathrm{sens}}^{\mathrm{ACD}} \times \Phi_{\mathrm{Eu}}^{\mathrm{Eu}}
$$

For the present responsive probes, $\Phi_{\mathrm{Eu}}^{\mathrm{Eu}}$ is determined by the nature of the conjugated $\mathrm{Eu}^{3+}$ complex. Thus, $\Phi_{\mathrm{Eu}}^{\mathrm{Eu}}$ is not supposed to vary with respect to $\mathrm{Zn}^{2+}$ and it corresponds to an upper limit for the overall quantum yield $\Phi_{\mathrm{Eu}}^{\mathrm{ACD}}$. On the contrary, $\eta_{\mathrm{sens}}^{\mathrm{ACD}}$ is expected to vary because of the conformational rearrangements occurring upon $\mathrm{Zn}^{2+}$ binding. In the case of $\mathbf{L Z F} 4^{\mathbf{A C D} \mid \mathbf{E} u}$ with the DO3Apic chelate, the metal-centered luminescence quantum yield

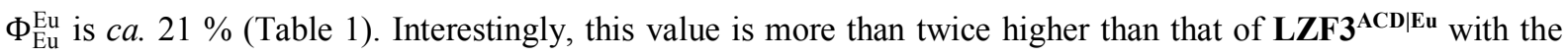
DOTA chelate ( $c$. $9.5 \%$ ), in line with values reported for related $\mathrm{Eu}^{3+}$ complexes of nonadentate DO3Apic derivatives $[69,84,89]$ and octadentate DOTA derivatives $[89,90]$. This confirms that the DO3Apic chelate is a valuable alternative to DOTA to improve the luminescence properties of $\mathrm{Ln}^{3+}$ complexes-peptide conjugates. In this system, $\eta_{\mathrm{sens}}^{\mathrm{ACD}}$ seems to be rather insensitive to the $\mathrm{Ln}^{3+}$ chelate nature, varying form $c a .0 .7 \%$ for both probes in their $\mathrm{Zn}$-free forms to $c a .5 \%$ for their $\mathrm{Zn}$-bound forms. However, these low values of $\eta_{\mathrm{sens}}^{\mathrm{ACD}}(<10 \%)$ are due to the remoteness of the antenna in comparison with coordinated antennas that offers higher sensitization efficiencies (20-100\%) [69,84,89-91]. The remoteness of the antenna and the subsequent low sensitization efficiency is clearly restricting the performance of these probes. Indeed, after having doubled $\Phi_{\mathrm{Eu}}^{\mathrm{Eu}}$ passing from DOTA to DO3Apic, optimization of the luminescence properties on this system requires now to minimize the antenna- $\mathrm{Ln}^{3+}$ distance in the $\mathrm{Zn}$-bound form.

Additionally, for $\mathbf{L Z F} 4^{\mathbf{A C D} \mid \mathbf{E} u}$, sensitization of $\mathrm{Eu}^{3+}$ luminescence may be achieved through excitation of the picolinamide chromophore around $280 \mathrm{~nm}$. Indeed, the $\mathrm{Eu}^{3+}$ emission intensity recovered after excitation at $283 \mathrm{~nm}$ remains unchanged upon $\mathrm{Zn}^{2+}$ binding (Fig. S5 of ESI) with $\Phi_{\mathrm{Eu}}^{\mathrm{pic}}=4.2 \%$ for both $\mathrm{Zn}$-free and $\mathrm{Zn}$-bound forms (Table 1), providing a signal for self-calibration. Hence, due to the DO3Apic chelate, $\mathbf{L Z F} \mathbf{4}^{\mathbf{A C D} \mid \mathbf{E u}}$ allows 
ratiometric detection of $\mathrm{Zn}^{2+}$ upon double wavelength excitation at $402 \mathrm{~nm}$ (responsive channel) and $283 \mathrm{~nm}$ (selfcalibration channel). Comparatively, $\Phi_{\mathrm{Eu}}^{\mathrm{pic}}$ is lower than the values reported for nonadentate $\mathrm{Eu}^{3+}$ complexes with picolinate arms such as DO3Apic chelators (9-24\%) [69] or other recently described pyclen-based chelators (23-

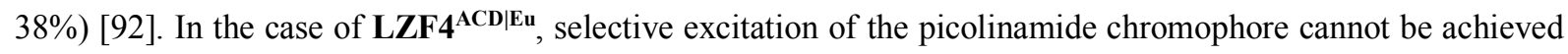
due to the overlap of its absorption and that of the acridone chromophore. This may be a reason for the reduced quantum yield. Another possibility is that that replacing the picolinate by a picolinamide decreases the quantum yield.

\title{
Conclusion
}

Generally, $\mathrm{Ln}^{3+}$ complex-peptide conjugates rely on the well-known octadentate DOTA ligand, which can be readily grafted onto a peptide using the DOTA-tris $(t \mathrm{Bu})$ ester building block. As $\mathrm{Ln}^{3+}$ complexes of DOTA are not coordinatively saturated, their luminescence properties are not optimal, especially regarding luminescence lifetime and quantum yield. In this article, we have described the solid phase synthesis of another building block, DO3Apic-tris(allyl)ester, and its use for the elaboration of peptide- $\mathrm{Ln}^{3+}$ complex conjugates with improved luminescence properties, with a $\mathrm{Zn}^{2+}$-responsive luminescent probe as an example. Indeed, DO3Apic offers a nonadentate coordination $\mathrm{N}, \mathrm{O}$ set in comparison with the octadentate coordination of DOTA. The comparison of $\mathbf{L Z F 3}^{\mathbf{A C D} \mid \mathbf{E u}}$ and $\mathbf{L Z F 4}^{\mathbf{A C D} \mid \mathbf{E u}}$ shows that the replacement DOTA for DO3Apic allows increasing the $\mathrm{Eu}^{3+}$ lifetime from $0.6 \mathrm{~ms}$ to $1.1 \mathrm{~ms}$ and more than doubling the intrinsic $\mathrm{Eu}^{3+}$ quantum yield as well as the overall quantum yield of the probe. This confirms that DO3Apic-tris(allyl)ester is an interesting building block for the design of luminescent $\mathrm{Ln}^{3+}$ complex-peptide conjugates. Additionally, in this system, the DO3Apic chelate offers the opportunity of self-calibration of the probe upon excitation of the picolinamide chromophore at $283 \mathrm{~nm}$. Hence, $\mathbf{L Z F}^{\mathrm{ACD} \mid \mathbf{E u}}$ is a nice example of ratiometric probe for time-resolved detection of $\mathrm{Zn}^{2+}$.

\section{Acknowledgements}

Authors acknowledge the Agence Nationale de la Recherche (ANR-12-BS07-0012), the Labex ARCANE and CBH-EUR-GS (ANR-17-EURE-0003) for financial support.

\author{
Abbreviations \\ ACD-OH 9-oxo-10(9H)-acridineacetic acid \\ Alloc allyloxycarbonyl \\ Boc tert-butyloxycarbonyl \\ Dap diaminopropionic acid \\ DIEA $\quad N, N$-diisopropylethylamine \\ DO3A 1,4,7,10-tetraazacyclododecane-1,4,7-triacetic acid \\ DOTA 1,4,7,10-tetraazacyclododecane-1,4,7,10-tetraacetic acid \\ DTPA diethylenetriaminepentacetic acid \\ EDTA ethylenediamine-tetraacetic acid \\ EGTA ethylene glycol-bis(2-aminoethylether)- $N, N, N^{\prime}, N^{\prime}$-tetraacetic acid \\ ESI electrospray ionization \\ Fmoc 9-fluorenylmethoxycarbonyl \\ HATU $\quad N$-[(dimethylamino)- $1 H$-1,2,3-triazolo[4,5-b]-pyridin-1-ylmethylene]- $N$-methylmethanaminium
}




$\begin{array}{ll} & \text { hexafluorophosphate N-oxide } \\ \text { HEDTA } & \text { N-hydroxyethyl-ethylenediamine-triacetic acid } \\ \text { HRMS } & \text { high resolution mass spectrometry } \\ \text { HPLC } & \text { high performance liquid chromatography } \\ \text { LRMS } & \text { low resolution mass spectrometry } \\ \text { MPAA } & \text { 4-mercaptophenylacetic acid } \\ \text { NTA } & \text { nitrilotriacetic acid } \\ \text { PyBOP } & \text { (Benzotriazol-1-yloxy)tripyrrolidino-phosphonium-hexafluorophosphate } \\ \text { SEA } & \text { bis(2-sulfanylethyl)-amino } \\ \text { SEA-PS } & \text { (bis(2-sulfanylethyl)-amino)-2-chlorotrityl-polystyrene } \\ t \text { Bu } & \text { tert-butyl } \\ \text { TCEP } & \text { tris(2-carboxyethyl)phosphine } \\ \text { TFA } & \text { trifluoroacetic acid } \\ \text { TFE } & 2,2,2 \text {-trifluoroethanol } \\ \text { Trt } & \text { trityl } \\ \text { UV-Vis } & \text { ultraviolet-visible }\end{array}$

\section{References}

[1] B. Valeur, Molecular Fluorescence: Principles and Applications, 1st ed., Wiley-VCH, Weinheim ; New York, 2001.

[2] E. Pazos, O. Vazquez, J.L. Mascareñas, M.E. Vázquez, Peptide-based fluorescent biosensors, Chem. Soc. Rev. 38 (2009) 3348-3359. https://doi.org/10.1039/b908546g.

[3] B. Hochreiter, A.P. Garcia, J.A. Schmid, Fluorescent Proteins as Genetically Encoded FRET Biosensors in Life Sciences, Sensors. 15 (2015) 26281-26314. https://doi.org/10.3390/s151026281.

[4] Q. Liu, J. Wang, B.J. Boyd, Peptide-based biosensors, Talanta. 136 (2015) 114-127. https://doi.org/10.1016/j.talanta.2014.12.020.

[5] K.P. Carter, A.M. Young, A.E. Palmer, Fluorescent Sensors for Measuring Metal Ions in Living Systems, Chem. Rev. 114 (2014) 4564-4601. https://doi.org/10.1021/cr400546e.

[6] A.M. Hessels, M. Merkx, Genetically-encoded FRET-based sensors for monitoring Zn2+ in living cells, Metallomics. 7 (2015) 258-266. https://doi.org/10.1039/C4MT00179F.

[7] J.A. González-Vera, Probing the kinome in real time with fluorescent peptides, Chem. Soc. Rev. 41 (2012) 1652-1664. https://doi.org/10.1039/c1cs15198c.

[8] T.W.B. Liu, J. Chen, G. Zheng, Peptide-based molecular beacons for cancer imaging and therapy, Amino Acids. 41 (2011) 1123-1134. https://doi.org/10.1007/s00726-010-0499-1.

[9] J. Zhang, X. Chai, X.-P. He, H.-J. Kim, J. Yoon, H. Tian, Fluorogenic probes for disease-relevant enzymes, Chem. Soc. Rev. 48 (2019) 683-722. https://doi.org/10.1039/C7CS00907K.

[10] B. Liu, B. Poolman, A.J. Boersma, Ionic Strength Sensing in Living Cells, ACS Chem. Biol. 12 (2017) 2510-2514. https://doi.org/10.1021/acschembio.7b00348.

[11] V.I. Martynov, A.A. Pakhomov, I.E. Deyev, A.G. Petrenko, Genetically encoded fluorescent indicators for live cell pH imaging, Biochim. Biophys. Acta-Gen. Subj. 1862 (2018) 2924-2939. https://doi.org/10.1016/j.bbagen.2018.09.013.

[12] S. Burgstaller, H. Bischof, T. Gensch, S. Stryeck, B. Gottschalk, J. Ramadani-Muja, E. Eroglu, R. Rost, S. Balfanz, A. Baumann, M. Waldeck-Weiermair, J.C. Hay, T. Madl, W.F. Graier, R. Malli, pH-Lemon, a Fluorescent Protein-Based pH Reporter for Acidic Compartments, ACS Sens. 4 (2019) 883-891. https://doi.org/10.1021/acssensors.8b01599.

[13] J.-C.G. Bünzli, Lanthanide Luminescence for Biomedical Analyses and Imaging, Chem. Rev. 110 (2010) 2729-2755. https://doi.org/10.1021/cr900362e.

[14] J.-C.G. Bünzli, Lanthanide light for biology and medical diagnosis, J. Lumin. 170 (2016) 866-878. https://doi.org/10.1016/j.jlumin.2015.07.033.

[15] M.C. Heffern, L.M. Matosziuk, T.J. Meade, Lanthanide Probes for Bioresponsive Imaging, Chem. Rev. 114 (2014) 4496-4539. https://doi.org/10.1021/cr400477t.

[16] M. Sy, A. Nonat, N. Hildebrandt, L.J. Charbonnière, Lanthanide-based luminescence biolabelling, Chem. Commun. 52 (2016) 5080-5095. https://doi.org/10.1039/C6CC00922K. 
[17] I. Martinić, S.V. Eliseeva, S. Petoud, Near-infrared emitting probes for biological imaging: Organic fluorophores, quantum dots, fluorescent proteins, lanthanide(III) complexes and nanomaterials, J. Lumin. 189 (2017) 19-43. https://doi.org/10.1016/j.jlumin.2016.09.058.

[18] G.-Q. Jin, Y. Ning, J.-X. Geng, Z.-F. Jiang, Y. Wang, J.-L. Zhang, Joining the journey to near infrared (NIR) imaging: the emerging role of lanthanides in the designing of molecular probes, Inorg. Chem. Front. 7 (2020) 289-299. https://doi.org/10.1039/C9QI01132C.

[19] J.-C.G. Bünzli, S.V. Eliseeva, Basics of Lanthanide Photophysics, in: P. Hänninen, H. Härmä (Eds.), Lanthanide Luminescence, Springer Berlin Heidelberg, 2011: pp. 1-45. http://link.springer.com/chapter/10.1007/4243_2010_3.

[20] S.I. Weissman, Intramolecular Energy Transfer The Fluorescence of Complexes of Europium, J. Chem. Phys. 10 (1942) 214-217. https://doi.org/10.1063/1.1723709.

[21] J.-C.G. Bünzli, On the design of highly luminescent lanthanide complexes, Coord. Chem. Rev. 293 (2015) 19-47. https://doi.org/10.1016/j.ccr.2014.10.013.

[22] E.J. New, D. Parker, D.G. Smith, J.W. Walton, Development of responsive lanthanide probes for cellular applications, Curr. Opin. Chem. Biol. 14 (2010) 238-246. https://doi.org/10.1016/j.cbpa.2009.10.003.

[23] A. Thibon, V.C. Pierre, Principles of responsive lanthanide-based luminescent probes for cellular imaging, Anal. Bioanal. Chem. 394 (2009) 107-120. https://doi.org/10.1007/s00216-009-2683-2.

[24] S.J. Bradberry, A.J. Savyasachi, M. Martinez-Calvo, T. Gunnlaugsson, Development of responsive visibly and NIR luminescent and supramolecular coordination self-assemblies using lanthanide ion directed synthesis, Coord. Chem. Rev. 273-274 (2014) 226-241. https://doi.org/10.1016/j.ccr.2014.03.023.

[25] X. Wang, H. Chang, J. Xie, B. Zhao, B. Liu, S. Xu, W. Pei, N. Ren, L. Huang, W. Huang, Recent developments in lanthanide-based luminescent probes, Coord. Chem. Rev. 273-274 (2014) 201-212. https://doi.org/10.1016/j.ccr.2014.02.001.

[26] C. Zhao, Y. Sun, J. Ren, X. Qu, Recent progress in lanthanide complexes for DNA sensing and targeting specific DNA structures, Inorg. Chim. Acta. 452 (2016) 50-61. https://doi.org/10.1016/j.ica.2016.04.014.

[27] S. Shuvaev, M. Starck, D. Parker, Responsive, Water-Soluble Europium(III) Luminescent Probes, Chem.Eur. J. 23 (2017) 9974-9989. https://doi.org/10.1002/chem.201700567.

[28] S.H. Hewitt, S.J. Butler, Application of lanthanide luminescence in probing enzyme activity, Chem. Commun. 54 (2018) 6635-6647. https://doi.org/10.1039/c8cc02824a.

[29] M.L. Aulsebrook, B. Graham, M.R. Grace, K.L. Tuck, Lanthanide complexes for luminescence-based sensing of low molecular weight analytes, Coord. Chem. Rev. 375 (2018) 191-220. https://doi.org/10.1016/j.ccr.2017.11.018.

[30] K. Iman, M. Shahid, Life sensors: current advances in oxygen sensing by lanthanide complexes, New J. Chem. 43 (2019) 1094-1116. https://doi.org/10.1039/C8NJ04993A.

[31] R.F.H. Viguier, A.N. Hulme, A sensitized europium complex generated by micromolar concentrations of copper(I): Toward the detection of copper(I) in biology, J. Am. Chem. Soc. 128 (2006) 11370-11371. https://doi.org/10.1021/ja064232v.

[32] J.P. Leonard, C.M.G. dos Santos, S.E. Plush, T. McCabe, T. Gunnlaugsson, pH driven self-assembly of a ternary lanthanide luminescence complex: the sensing of anions using a beta-diketonate-Eu(III) displacement assay, Chem. Commun. (2007) 129-131. https://doi.org/10.1039/b611487c.

[33] K. Lee, V. Dzubeck, L. Latshaw, J.P. Schneider, De novo designed peptidic redox potential probe: Linking sensitized emission to disulfide bond formation, J. Am. Chem. Soc. 126 (2004) 13616-13617. https://doi.org/10.1021/ja047300r.

[34] M. Halim, M.S. Tremblay, S. Jockusch, N.J. Turro, D. Sames, Transposing molecular fluorescent switches into the Near-IR: Development of luminogenic reporter substrates for redox metabolism, J. Am. Chem. Soc. 129 (2007) 7704-7705. https://doi.org/10.1021/ja071311d.

[35] E. Pershagen, J. Nordholm, K.E. Borbas, Luminescent Lanthanide Complexes with Analyte-Triggered Antenna Formation, J. Am. Chem. Soc. 134 (2012) 9832-9835. https://doi.org/10.1021/ja3004045.

[36] B. Song, G. Wang, M. Tan, J. Yuan, A europium(III) complex as an efficient singlet oxygen luminescence probe, J. Am. Chem. Soc. 128 (2006) 13442-13450. https://doi.org/10.1021/ja062990f.

[37] Y. Chen, W. Guo, Z. Ye, G. Wang, J. Yuan, A europium(III) chelate as an efficient time-gated luminescent probe for nitric oxide, Chem. Commun. 47 (2011) 6266-6268. https://doi.org/10.1039/c0cc05658h.

[38] Z. Dai, L. Tian, B. Song, Z. Ye, X. Liu, J. Yuan, Ratiometric Time-Gated Luminescence Probe for Hydrogen Sulfide Based on Lanthanide Complexes, Anal. Chem. 86 (2014) 11883-11889. https://doi.org/10.1021/ac503611f.

[39] M. Isaac, S.A. Denisov, A. Roux, D. Imbert, G. Jonusauskas, N.D. McClenaghan, O. Sénèque, Lanthanide Luminescence Modulation by Cation- $\pi$ Interaction in a Bioinspired Scaffold: Selective Detection of Copper(I), Angew. Chem., Int. Ed. 54 (2015) 11453-11456. https://doi.org/10.1002/anie.201505733.

[40] D.G. Smith, R. Pal, D. Parker, Measuring Equilibrium Bicarbonate Concentrations Directly in Cellular Mitochondria and in Human Serum Using Europium/Terbium Emission Intensity Ratios, Chem.-Eur. J. 18 
(2012) 11604-11613. https://doi.org/10.1002/chem.201201738.

[41] B.K. McMahon, R. Pal, D. Parker, A bright and responsive europium probe for determination of $\mathrm{pH}$ change within the endoplasmic reticulum of living cells, Chem. Commun. 49 (2013) 5363-5365. https://doi.org/10.1039/C3CC42308E.

[42] G.-L. Law, R. Pal, L.O. Palsson, D. Parker, K.-L. Wong, Responsive and reactive terbium complexes with an azaxanthone sensitiser and one naphthyl group: applications in ratiometric oxygen sensing in vitro and in regioselective cell killing, Chem. Commun. (2009) 7321-7323. https://doi.org/10.1039/b920222f.

[43] T.J. Sørensen, A.M. Kenwright, S. Faulkner, Bimetallic lanthanide complexes that display a ratiometric response to oxygen concentrations, Chem. Sci. 6 (2015) 2054-2059. https://doi.org/10.1039/C4SC03827D.

[44] M. Delbianco, V. Sadovnikova, E. Bourrier, G. Mathis, L. Lamarque, J.M. Zwier, D. Parker, Bright, Highly Water-Soluble Triazacyclononane Europium Complexes To Detect Ligand Binding with Time-Resolved FRET Microscopy, Angew. Chem., Int. Ed. 53 (2014) 10718-10722. https://doi.org/10.1002/anie.201406632.

[45] Z. Dai, L. Tian, B. Song, X. Liu, J. Yuan, Development of a novel lysosome-targetable time-gated luminescence probe for ratiometric and luminescence lifetime detection of nitric oxide in vivo, Chem. Sci. 8 (2017) 1969-1976. https://doi.org/10.1039/C6SC03667H.

[46] Y. Bretonnière, M.J. Cann, D. Parker, R. Slater, Ratiometric probes for hydrogencarbonate analysis in intracellular or extracellular environments using europium luminescence, Chem. Commun. (2002) 19301931. https://doi.org/10.1039/B206286K.

[47] R. Pal, D. Parker, A single component ratiometric $\mathrm{pH}$ probe with long wavelength excitation of europium emission, Chem. Commun. (2007) 474-476. https://doi.org/10.1039/b616665b.

[48] D.G. Smith, B.K. McMahon, R. Pal, D. Parker, Live cell imaging of lysosomal pH changes with pH responsive ratiometric lanthanide probes, Chem. Commun. 48 (2012) 8520-8522. https://doi.org/10.1039/c2cc34267g.

[49] L.B. Jennings, S. Shuvaev, M.A. Fox, R. Pal, D. Parker, Selective signalling of glyphosate in water using europium luminescence, Dalton Trans. 47 (2018) 16145-16154. https://doi.org/10.1039/C8DT03823F.

[50] T. Hirayama, M. Taki, K. Akaoka, Y. Yamamoto, Development of a dual functional luminescent sensor for zinc ion based on a peptidic architecture, Bioorg. Med. Chem. Lett. 22 (2012) 7410-7413. https://doi.org/10.1016/j.bmcl.2012.10.061.

[51] M. Isaac, L. Raibaut, C. Cepeda, A. Roux, D. Boturyn, S.V. Eliseeva, S. Petoud, O. Sénèque, Luminescent Zinc Fingers: Zn-Responsive Neodymium Near-Infrared Emission in Water, Chem.-Eur. J. 23 (2017) 10992-10996. https://doi.org/10.1002/chem.201703089.

[52] E. Pazos, D. Torrecilla, M.V. Lopez, L. Castedo, J.L. Mascareñas, A. Vidal, M.E. Vázquez, Cyclin A probes by means of intermolecular sensitization of terbium-chelating peptides, J. Am. Chem. Soc. 130 (2008) 9652-+. https://doi.org/10.1021/ja803520q.

[53] H.E. Rajapakse, N. Gahlaut, S. Mohandessi, D. Yu, J.R. Turner, L.W. Miller, Time-resolved luminescence resonance energy transfer imaging of protein-protein interactions in living cells, Proc. Natl. Acad. Sci. U. S. A. 107 (2010) 13582-13587. https://doi.org/10.1073/pnas.1002025107.

[54] E. Pazos, A. Jimenez-Balsa, J.L. Mascareñas, M.E. Vázquez, Sensing coiled-coil proteins through conformational modulation of energy transfer processes - selective detection of the oncogenic transcription factor c-Jun, Chem. Sci. 2 (2011) 1984-1987. https://doi.org/10.1039/c1sc00108f.

[55] H.-K. Kong, F.L. Chadbourne, G.-L. Law, H. Li, H.-L. Tam, S.L. Cobb, C.-K. Lau, C.-S. Lee, K.-L. Wong, Two-photon induced responsive $\mathrm{f}-\mathrm{f}$ emissive detection of Cyclin A with a europium-chelating peptide, Chem. Commun. 47 (2011) 8052-8054. https://doi.org/10.1039/C1CC12811F.

[56] C. Penas, E. Pazos, J.L. Mascareñas, M.E. Vázquez, A Folding-Based Approach for the Luminescent Detection of a Short RNA Hairpin, J. Am. Chem. Soc. 135 (2013) 3812-3814. https://doi.org/10.1021/ja400270a.

[57] C. Penas, J.L. Mascareñas, M.E. Vázquez, Coupling the folding of a $\beta$-hairpin with chelation-enhanced luminescence of $\mathrm{Tb}(\mathrm{III})$ and $\mathrm{Eu}(\mathrm{III})$ ions for specific sensing of a viral RNA, Chem. Sci. 7 (2016) 26742678. https://doi.org/10.1039/C5SC04501K.

[58] L. Raibaut, W. Vasseur, G.D. Shimberg, C. Saint-Pierre, J.-L. Ravanat, S.L.J. Michel, O. Sénèque, Design of a synthetic luminescent probe from a biomolecule binding domain: selective detection of AU-rich mRNA sequences, Chem. Sci. 8 (2017) 1658-1664. https://doi.org/10.1039/C6SC04086A.

[59] M.S. Tremblay, M. Lee, D. Sames, A luminescent sensor for tyrosine phosphorylation, Org. Lett. 10 (2008) 5-8. https://doi.org/10.1021/ol701920x.

[60] E. Pazos, M. Golicnik, J.L. Mascareñas, M.E. Vázquez, Detection of phosphorylation states by intermolecular sensitization of lanthanide-peptide conjugates, Chem. Commun. 48 (2012) 9534-9536. https://doi.org/10.1039/c2cc34958b.

[61] J.A. González-Vera, D. Bouzada, C. Bouclier, M.E. Vázquez, M.C. Morris, Lanthanide-based peptide biosensor to monitor CDK4/cyclin D kinase activity, Chem. Commun. 53 (2017) 6109-6112. 
https://doi.org/10.1039/C6CC09948C.

[62] A. Heppeler, S. Froidevaux, H.R. Macke, E. Jermann, M. Behe, P. Powell, M. Hennig, Radiometal-labelled macrocyclic chelator-derivatised somatostatin analogue with superb tumour-targeting properties and potential for receptor-mediated internal radiotherapy, Chem.-Eur. J. 5 (1999) 1974-1981. https://doi.org/10.1002/(SICI)1521-3765(19990702)5:7<1974::AID-CHEM1974>3.0.CO;2-X.

[63] B. Jagadish, G.L. Brickert-Albrecht, G.S. Nichol, E.A. Mash, N. Raghunand, On the synthesis of 1,4,7tris(tert-butoxycarbonylmethyl)-1,4,7,10-tetraazacyclododecane, Tetrahedron Lett. 52 (2011) 2058-2061. https://doi.org/10.1016/j.tetlet.2010.10.074.

[64] Y. Arano, T. Uezono, H. Akizawa, M. Ono, K. Wakisaka, M. Nakayama, H. Sakahara, J. Konishi, A. Yokoyama, Reassessment of Diethylenetriaminepentaacetic Acid (DTPA) as a Chelating Agent for Indium-111 Labeling of Polypeptides Using a Newly Synthesized Monoreactive DTPA Derivative, J. Med. Chem. 39 (1996) 3451-3460. https://doi.org/10.1021/jm950949+.

[65] F. Leclercq, M. Cohen-Ohana, N. Mignet, A. Sbarbati, J. Herscovici, D. Scherman, G. Byk, Design, synthesis, and evaluation of gadolinium cationic lipids as tools for biodistribution studies of gene delivery complexes, Bioconjugate Chem. 14 (2003) 112-119. https://doi.org/10.1021/bc025567e.

[66] M. Isaac, A. Pallier, F. Szeremeta, P.-A. Bayle, L. Barantin, C.S. Bonnet, O. Sénèque, MRI and luminescence detection of $\mathrm{Zn} 2+$ with a lanthanide complex-zinc finger peptide conjugate, Chem. Commun. 54 (2018) 7350-7353. https://doi.org/10.1039/C8CC04366C.

[67] G. Schwarzenbach, H. Flaschka, Complexometric titrations, Methuen, London, 1969.

[68] M. Whiting, K. Harwood, F. Hossner, P.G. Turner, M.C. Wilkinson, Selection and Development of the Manufacturing Route for EP1 Antagonist GSK269984B, Org. Process Res. Dev. 14 (2010) 820-831. https://doi.org/10.1021/op100072y.

[69] M. Regueiro-Figueroa, B. Bensenane, E. Ruscsak, D. Esteban-Gomez, L.J. Charbonniere, G. Tircso, I. Toth, A. de Blas, T. Rodriguez-Blas, C. Platas-Iglesias, Lanthanide dota-like Complexes Containing a Picolinate Pendant: Structural Entry for the Design of Ln(III)-Based Luminescent Probes, Inorg. Chem. 50 (2011) 4125-4141. https://doi.org/10.1021/ic2001915.

[70] N. Ollivier, L. Raibaut, A. Blanpain, R. Desmet, J. Dheur, R. Mhidia, E. Boll, H. Drobecq, S.L. Pira, O. Melnyk, Tidbits for the synthesis of bis(2-sulfanylethyl)amido (SEA) polystyrene resin, SEA peptides and peptide thioesters, J. Pept. Sci. 20 (2014) 92-97. https://doi.org/10.1002/psc.2580.

[71] N. Thieriet, J. Alsina, E. Giralt, F. Guibe, F. Albericio, Use of Alloc-amino acids in solid-phase peptide synthesis. Tandem deprotection-coupling reactions using neutral conditions., Tetrahedron Lett. 38 (1997) 7275-7278. https://doi.org/10.1016/S0040-4039(97)01690-0.

[72] E. Boll, H. Drobecq, N. Ollivier, A. Blanpain, L. Raibaut, R. Desmet, J. Vicogne, O. Melnyk, One-pot chemical synthesis of small ubiquitin-like modifier protein-peptide conjugates using bis(2-sulfanylethyl) amido peptide latent thioester surrogates, Nat. Protoc. 10 (2015) 269-292. https://doi.org/10.1038/nprot.2015.013.

[73] A.M. Brouwer, Standards for photoluminescence quantum yield measurements in solution (IUPAC Technical Report), Pure Appl. Chem. 83 (2011) 2213-2228. https://doi.org/10.1351/PAC-REP-10-09-31.

[74] U. Resch-Genger, K. Rurack, Determination of the photoluminescence quantum yield of dilute dye solutions (IUPAC Technical Report), Pure Appl. Chem. 85 (2013) 2005-2013. https://doi.org/10.1351/PAC-REP-12-03-03.

[75] A. Beeby, I.M. Clarkson, R.S. Dickins, S. Faulkner, D. Parker, L. Royle, A.S. de Sousa, J.A.G. Williams, M. Woods, Non-radiative deactivation of the excited states of europium, terbium and ytterbium complexes by proximate energy-matched $\mathrm{OH}, \mathrm{NH}$ and $\mathrm{CH}$ oscillators: an improved luminescence method for establishing solution hydration states, J. Chem. Soc., Perkin Trans. 2. (1999) 493-504. https://doi.org/10.1039/A808692C.

[76] A.E. Martell, R.M. Smith, Critical Stability Constants, Plenum Press, New York, 1974.

[77] R.M. Smith, A.E. Martell, R.J. Motekaitis, Critically Selected Stability Constants of Metal Complexes Database. NIST Standard Reference Database 46, 2001.

[78] E. Deiters, F. Gumy, J.-C.C. Buenzli, Acridone-Benzimidazole Ring-Fused Ligands: A New Class of Sensitizers of Lanthanide Luminescence via Low-Energy Excitation, Eur. J. Inorg. Chem. (2010) 27232734. https://doi.org/10.1002/ejic.200901148.

[79] J.D. Routledge, M.W. Jones, S. Faulkner, M. Tropiano, Kinetically Stable Lanthanide Complexes Displaying Exceptionally High Quantum Yields upon Long-Wavelength Excitation: Synthesis, Photophysical Properties, and Solution Speciation, Inorg. Chem. 54 (2015) 3337-3345. https://doi.org/10.1021/ic503049m.

[80] C. Szijjarto, E. Pershagen, N.O. Ilchenko, K.E. Borbas, A Versatile Long-Wavelength-Absorbing Scaffold for Eu-Based Responsive Probes, Chem.-Eur. J. 19 (2013) 3099-3109. https://doi.org/10.1002/chem.201203957.

[81] A. Dadabhoy, S. Faulkner, P.G. Sammes, Small singlet-triplet energy gap of acridone enables longer 
wavelength sensitisation of europium(III) luminescence, J. Chem. Soc., Perkin Trans. 2. (2000) 2359-2360. https://doi.org/10.1039/B008179P.

[82] A. Dadabhoy, S. Faulkner, P.G. Sammes, Long wavelength sensitizers for europium(III) luminescence based on acridone derivatives, J. Chem. Soc., Perkin Trans. 2. (2002) 348-357. https://doi.org/10.1039/b104541p.

[83] Y. Bretonniere, M.J. Cann, D. Parker, R. Slater, Design, synthesis and evaluation of ratiometric probes for hydrogencarbonate based on europium emission, Org. Biomol. Chem. 2 (2004) 1624-1632. https://doi.org/10.1039/B400734B.

[84] A. D’Aléo, M. Allali, A. Picot, P.L. Baldeck, L. Toupet, C. Andraud, O. Maury, Sensitization of Eu(III) luminescence by donor-phenylethynyl-functionalized DTPA and DO3A macrocycles, C. R. Chim. 13 (2010) 681-690. https://doi.org/10.1016/j.crci.2010.01.008.

[85] W.I. O’Malley, E.H. Abdelkader, M.L. Aulsebrook, R. Rubbiani, C.-T. Loh, M.R. Grace, L. Spiccia, G. Gasser, G. Otting, K.L. Tuck, B. Graham, Luminescent Alkyne-Bearing Terbium(III) Complexes and Their Application to Bioorthogonal Protein Labeling, Inorg. Chem. 55 (2016) 1674-1682. https://doi.org/10.1021/acs.inorgchem.5b02605.

[86] W. Mier, K. a. N. Graham, Q. Wang, S. Kramer, J. Hoffend, M. Eisenhut, U. Haberkorn, Synthesis of peptide conjugated chelator oligomers for endoradiotherapy and MRT imaging, Tetrahedron Lett. 45 (2004) 5453-5455. https://doi.org/10.1016/j.tetlet.2004.05.034.

[87] B. Wängler, C. Beck, U. Wagner-Utermann, E. Schirrmacher, C. Bauer, F. Roesch, R. Schirrmacher, M. Eisenhut, Application of tris-allyl-DOTA in the preparation of DOTA-peptide conjugates, Tetrahedron Lett. 47 (2006) 5985-5988. https://doi.org/10.1016/j.tetlet.2006.06.022.

[88] M.H.V. Werts, R.T.F. Jukes, J.W. Verhoeven, The emission spectrum and the radiative lifetime of Eu3+ in luminescent lanthanide complexes, Phys. Chem. Chem. Phys. 4 (2002) 1542-1548. https://doi.org/10.1039/b107770h.

[89] D. Kovacs, S.R. Kiraev, D. Phipps, A. Orthaber, K.E. Borbas, Eu(III) and Tb(III) Complexes of Octa- and Nonadentate Macrocyclic Ligands Carrying Azide, Alkyne, and Ester Reactive Groups, Inorg. Chem. 59 (2020) 106-117. https://doi.org/10.1021/acs.inorgchem.9b01576.

[90] D. Kovacs, D. Phipps, A. Orthaber, K.E. Borbas, Highly luminescent lanthanide complexes sensitised by tertiary amide-linked carbostyril antennae, Dalton Trans. 47 (2018) 10702-10714. https://doi.org/10.1039/C8DT01270A

[91] J. Andres, A.-S. Chauvin, Energy transfer in coumarin-sensitised lanthanide luminescence: investigation of the nature of the sensitiser and its distance to the lanthanide ion, Phys. Chem. Chem. Phys. 15 (2013) 15981-15994. https://doi.org/10.1039/c3cp52279b.

[92] M. Le Fur, E. Molnár, M. Beyler, O. Fougère, D. Esteban-Gómez, O. Rousseaux, R. Tripier, G. Tircsó, C. Platas-Iglesias, Expanding the Family of Pyclen-Based Ligands Bearing Pendant Picolinate Arms for Lanthanide Complexation, Inorg. Chem. 57 (2018) 6932-6945.

https://doi.org/10.1021/acs.inorgchem.8b00598. 